\title{
Historic Overview and Archival Archaeological Investigations for the San Antonio River Improvements Project: Houston to Lexington Segment
}

\author{
I. Waynne Cox \\ Center for Archaeological Research \\ Cynthia L. Tennis \\ Center for Archaeological Research
}

Follow this and additional works at: https://scholarworks.sfasu.edu/ita

Part of the American Material Culture Commons, Archaeological Anthropology Commons, Environmental Studies Commons, Other American Studies Commons, Other Arts and Humanities Commons, Other History of Art, Architecture, and Archaeology Commons, and the United States History Commons

Tell us how this article helped you.

This Article is brought to you for free and open access by the Center for Regional Heritage Research at SFA ScholarWorks. It has been accepted for inclusion in Index of Texas Archaeology: Open Access Gray Literature from the Lone Star State by an authorized editor of SFA ScholarWorks. For more information, please contact cdsscholarworks@sfasu.edu. 
Historic Overview and Archival Archaeological Investigations for the San Antonio River Improvements Project: Houston to Lexington Segment

\section{Creative Commons License}

\section{(c) (1) \&}

This work is licensed under a Creative Commons Attribution-NonCommercial 4.0 International License 


\title{
Historic Overview and Archival Archaeological Investigation for the San Antonio River Improvements Project:
}

\author{
Houston to \\ Lexington Segment
}

I. Waynne Cox and Cynthia L. Tennis

Robert J. Hard and C. Britt Bousman, Principal Investigators

Texas Antiquities Permit No. 2181

${ }^{\circ}$ copyright 2000

Center for Archaeological Research

The University of Texas at San Antonio

Archaeological Survey Report, No. 299 
The following information is provided in accordance with the General Rules of Practice and Procedure, Chapter 41.11 (Investigative Reports), Texas Antiquities Committee:

1. Type of investigation: Archival Research.

2. Project name: San Antonio River Improvements - Archival.

3. County: Bexar.

4. Principal investigator: Robert J. Hard and C. Britt Bousman.

5. Name and location of sponsoring agency: San Antonio River Authority (SARA), San Antonio, Texas, 78204

6. Texas Antiquities Permit No.: 2181

7. Published by the Center for Archaeological Research, The University of Texas at San Antonio, 6900 N. Loop 1604 W., San Antonio, Texas 78249-0658, 2000

A list of publications offered by the Center for Archaeological Research is available. Call (210) 458-4378; write to the Center for Archaeological Research, The University of Texas at San Antonio, 6900 N. Loop 1604 W., San Antonio, Texas 78249-0658; e-mail to car@lonestar.utsa.edu; or visit CAR's web site at http://csbs3.utsa.edu/car. 


\begin{abstract}
In April 1999, the Centre for Archaeological Research (CAR) of The University of Texas at San Antonio (UTSA) provided archival research and assessment of the Houston Street to Lexington Avenue portion of the San Antonio River Improvements Project. This undertaking enabled archival research to precede the initiation of the San Antonio River Improvements Project in order to identify areas of potentially significant cultural resources within the project area. In this capacity, CAR served as consultants to PBS\&J, Engineering and Environmental Consulting for their client, the San Antonio River Authority (SARA), on the San Antonio River Improvements Project (Houston Street to Lexington Avenue) Environmental/Historical Services. The scope of the archaeological research and assessment was performed under Texas Historical Commission Permit Number 2181. The process included a thorough search of archival records documenting historic land use and ownership, documentation and assessments of the presence and location of historic structures and/or cultural deposits. The archival portion includes the integration of archaeological information with engineering and architectural plans to identify areas of potentially significant, intact, cultural resources within the project area and report on same.

Two historic sites were identified and recorded during site inspection visits. One site, recorded as 41BX1369, is the historic location of the ca. 1866 Laux Mill and Dam currently incorporated within the Hugman water feature, just north of Travis Street. The second site, recorded as 41BX1370, is an artifact deposit in the pilotchannel beneath the Travis Street Bridge, thought to be associated with the 1842 Jaques home. Recommendations for avoidance or monitoring of improvements in these specific areas, in addition to recommendations for monitoring all other subsurface disturbances, were made.
\end{abstract}




\section{Contents}

Abstract fon

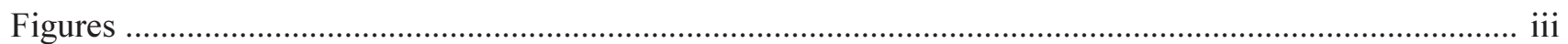

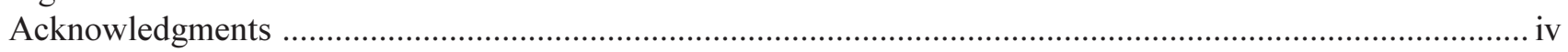

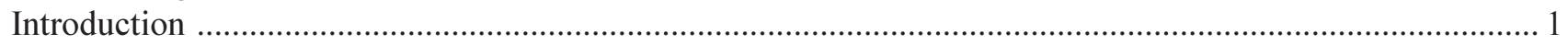

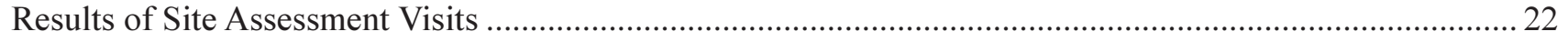

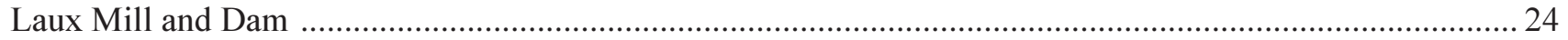

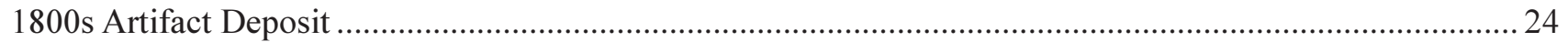

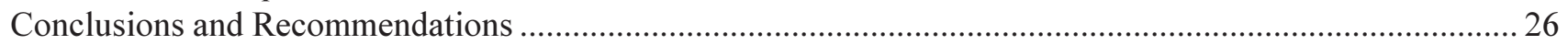

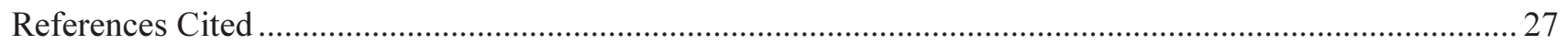

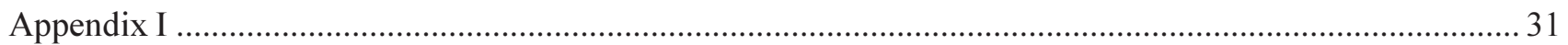




\section{Figures}

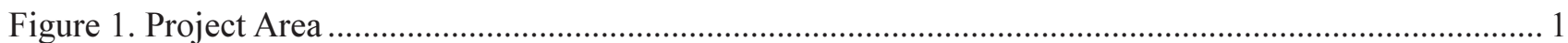

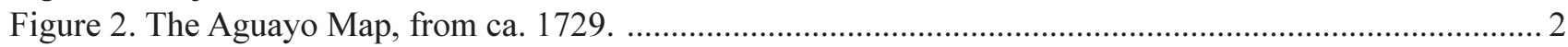

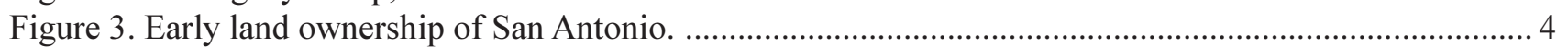

Figure 4. Adaptation of 1896 Sanborn map showing Jaques House, Paschel House, and Laux Mill site. ......... 6

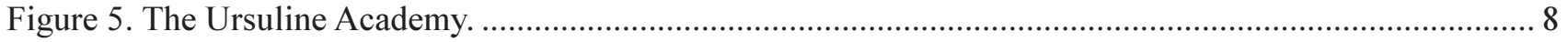

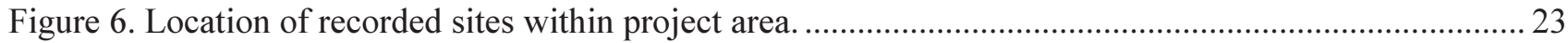

Figure 7. 41BX1369 - Hugman water feature, probable location of Laux Mill.............................................. 24

Figure 8. Photo of Laux Mill (n.d.) published June 10, 1930, from the San Antonio Light collection. .......... 25

Figure 9. 41BX1370 - Artifact deposit beneath pilot-channel retaining wall ................................................ 26 


\section{Acknowledgments}

This report represents the archaeological portion of a multi-faceted historical and environmental assessment conducted for the San Antonio River Association (SARA). We would like to recognize the assistance of Cecilia Green and Eugene Foster from the lead agency PBS\&J. We would also like to thank Steve Graham, SARA, for acknowledging the need for archaeological and historical assessment during the design phase of the improvement project along the San Antonio River. 


\section{Introduction}

In April 1999, the Center for Archaeological Research (CAR), at The University of Texas at San Antonio (UTSA), as consultants to PBS\&J, and their client the San Antonio River Authority (SARA), entered into a professional services agreement for the San Antonio River Improvements Project (Houston Street to Lexington Avenue) (Figure 1). This project was conducted under Texas Historical Permit (THC) Number 2181 in consultation with the regulatory branch of the U.S. Army Corps. of Engineers (COE).

The archaeological commitment was to provide archival research to precede project initiation and was designed to identify potentially significant cultural resources within the area of consideration. The research consisted of investigations in the Bexar County Courthouse; Spanish Archives, San Antonio Library; Daughters of the Republic of Texas Library; archives of the San Antonio River Authority; files of CARUTSA, and communication with the Mother House of the Ursuline Academy located in Crystal City, Missouri.

\section{Founding of the City and First Acequias}

On April 9, 1718, Governor Don Martín de Alarcón, accompanied by Father Antonio de San Buenaventura y Olivares and seven families of settlers, crossed the Río Grande and arrived at the San Antonio River on April 25. Father Olivares established a temporary location for his mission San Antonio de Valero, later and in another location to gain fame as the Alamo, half a league below the high ground near San Pedro Springs. On May 5, 1718, Alarcón established the Villa de Bejar, near the same springs (Hoffman 1935:43). Excavations for the first acequia (irrigation ditch), began shortly thereafter. It was observed "there is opportunity for opening one irrigation ditch with ease and no more" (Castañeda 1936:Vol. 2, p. 92). This first acequia was short-lived, and over the next two and one-half centuries, as the City of San Antonio grew, no physical trace of this small unlined ditch had been found. However, archives and several land transactions point to the existence of an abandoned and forgotten acequia which emanated from the vicinity of San Pedro Springs and returned to the San Antonio River.

Almost sixty years later, another acequia is mentioned with the distribution of lands served by a "new" ditch, the Upper Labor, constructed in 1776 and 1777. Two grants were issued to the north of the newly irrigated lands to Francisco Xavier Rodríguez and Vincente Flores that specify the eastern boundary of their lands as being along the ditch of the "Labor Alta" (Bexar County Archives [BCA], Spanish Archives [SA], Office of the County Clerk, Bexar County Courthouse, San Antonio, Vol. 2, p. 474:Vol. 3, p. 333). A re-platting

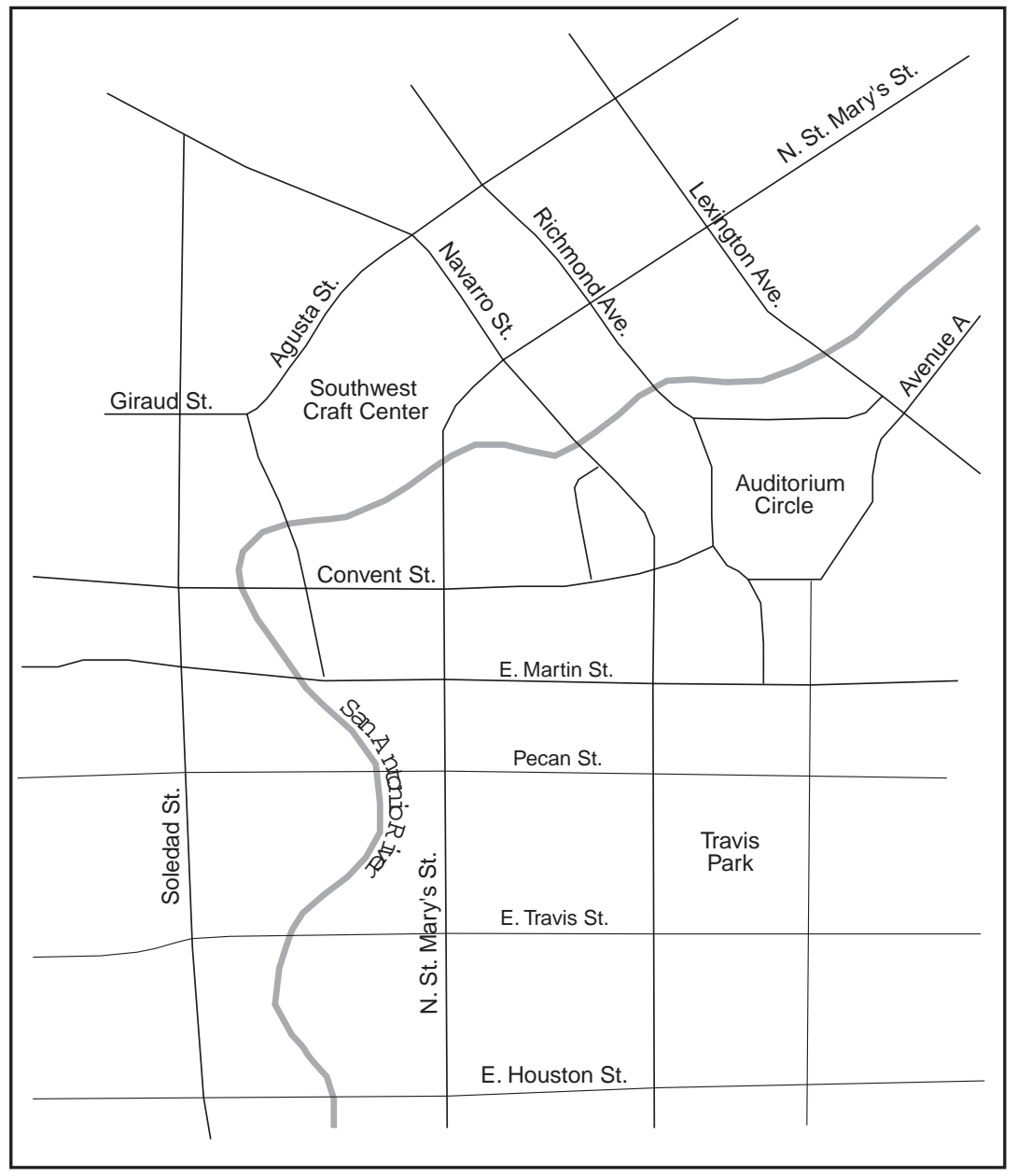

Figure 1. Project area. 
of the metes and bounds of these grants establishes that the bordering ditch originated on the eastern edge of the springs and flowed toward the southeast 471 varas $(1,308$ feet) to the east of the creek, where it turned slightly more toward the east to intersect with a projection of a line of what is now known as Richmond Avenue. A later survey, 1847, shows the ditch, still in existence, following the paths of Richmond and Lexington avenues toward the southeast and discharging into the San Antonio River at the northern corner of a large curve in the river which has since been obliterated by the construction of the Municipal Auditorium (Figure 1) (UTSAArchives, Institute of Texan Cultures, Stewart Abstract Collection, Block 31, City Block 302). This ditch, approximately 1.33 miles long, would have supplied the irrigation needs of 300 acres of land southeast of the springs between the creek and the river.

In 1720, José de Azlor y Virto de Vera, Marqués de San Miguel de Aguayo, governor and captain general of the provinces of Coahuila and Texas, received a commission from the viceroy of New Spain to reoccupy the East Texas missions and presidios that had been abandoned during the French invasion of 1719. Upon his return to San Antonio, in January 1722, he learned that the presidio had burned. Sixteen huts and the granary, with its stores of 700 bushels of corn, had been destroyed. Faced with this destruction, he ordered that the Presidio be relocated to a site between the river and San Pedro Creek (presently Military Plaza) opposite the new site of Mission San Antonio de Valero. He designed the fortress "as a square with four bulwarks and curtain walls 65 varas [180.5 feet] in length." He also ordered, at his expense, that an acequia be constructed from San Pedro Creek to serve the new location (Turanza 1961:75-76; Santos 1981:75-76). As is often the case, archival records fail to indicate the location selected for this new acequia; however, in this case there is a reference in the Aguayo map (Figure 2).

This map, reputedly produced by the Marqués for Viceroy Casafuente in 1729, has been dismissed as "charming" but "inaccurate in scale and geographic features" (Schuetz 1968:11). It has been further criticized because it places the loop of the river on the wrong side, the confluence of San Pedro Creek and the river incorrectly, and Mission San José y San Miguel on the wrong side of the river (de la Teja 1995:54). However, if viewed as a representation of the area as it appeared when last seen by Aguayo upon his departure in 1722 , an entirely different interpretation can be drawn.

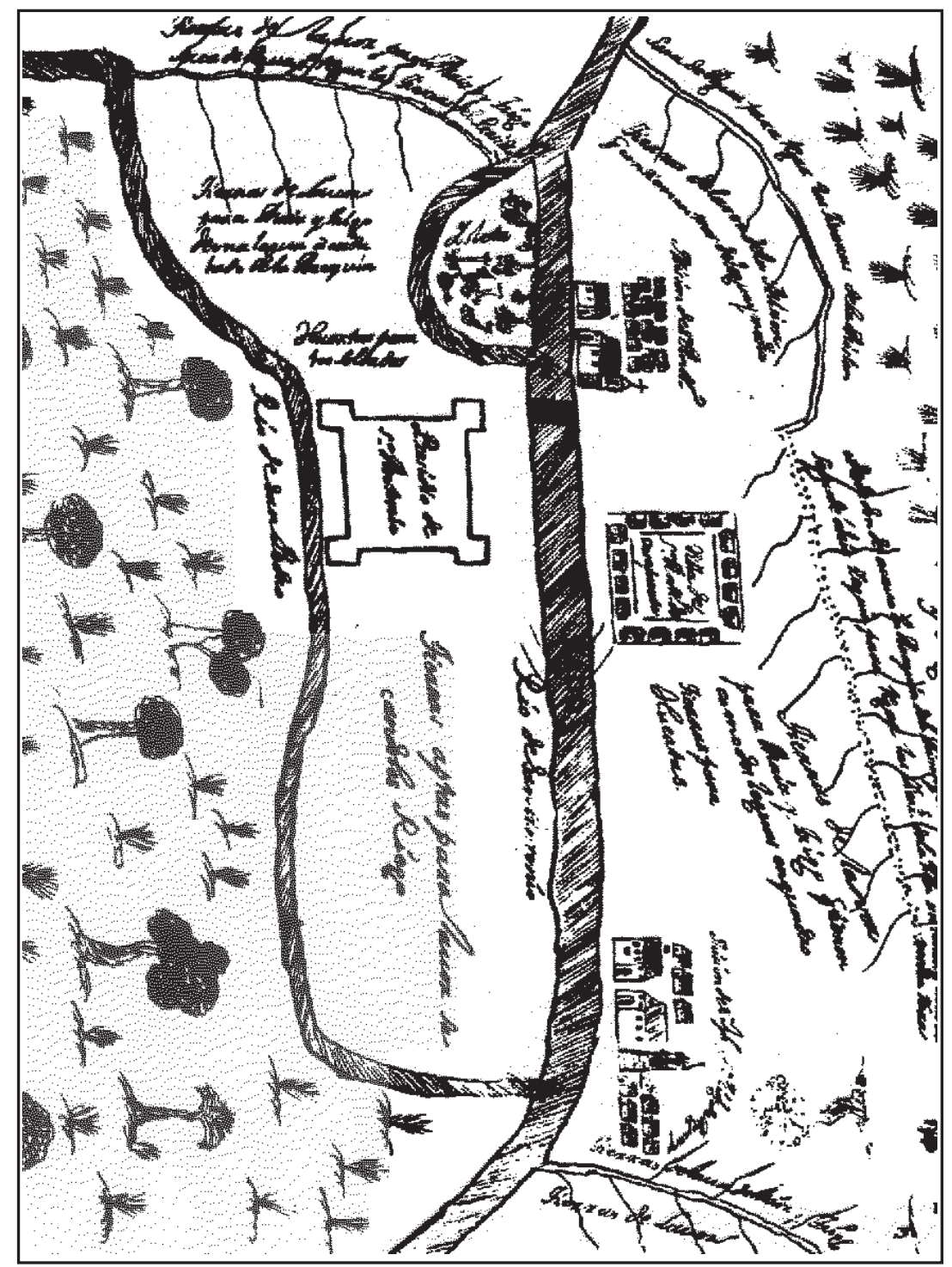

Figure 2. The Aguayo Map, from ca. 1729. 
Although the river is clearly not depicted in correct detail, San Pedro Creek is definitely represented in a realistic manner, and the loop of the river shown can be identified as the portion of the horseshoe bend now recognized as the Riverwalk, that does project toward the west. This indicates that the presidio acequia emanated from the first major bend of the creek then curved to the southwest to return to the river near the beginning of the river bend, which would place it within the current project area. The canal would have been approximately 4,000 feet long and would have provided irrigation to 100 acres above the site of the presidio. There is evidence that this ditch remained as late as 1920 (San Antonio Express [SAE], December 19, 1920).

\section{Distribution of the Lands}

The Spanish missions of Texas were not intended to be permanent institutions. With the secularization decree of April 10, 1794, the Spanish government declared that the padres had accomplished their purpose, the mission property and land were to be distributed among the Native converts, and the church turned over to secular clergy. The lands of San Antonio de Valero were given to the Natives of the missions and the displaced citizens of the East Texas settlements of Los Adaes.

In 1808 , suerte (or lot number) 19 was granted to the Adaesaño Ambrosio Rodríguez (Figure 3), and two decades later the property was listed in the will of his heir, Maria Gertrudes de los Santo Coy (Bexar County Deed Records [BCDR] Vol. H1, p. 45). This lot was located at the corner of Calle Rincon (St. Mary's Street) and Calle Paseo (Houston Street) and bounded on the west by the San Antonio River, presently a portion of New City Block (NCB) 403 (BCDR Vol. M2, p. 155). This property was conveyed by María Jesus Rodríguez, José María Rodríguez, and Guadalupe Rodríguez to James and William Vance in January, 1851 (BCDR Vol. I2, p. 240).

Across the river, the lands fronting Soledad Street were granted by the Spanish government to Miguel de Castro in May, 1738 (BCA-SA, Vol. 2, p. 243). This property later passed to the heirs of Marcos Zepeda and was conveyed to Vincente Treviño in December, 1824 (BCDR, Vol. F1, p. 90). Marcos Zepeda, born 1748, came to San Antonio from Los Adaes where he had served in the army from 1768 to 1772 (Chabot 1937, p. 219). Vincente Treviño married Marcos' daughter, María Catarina de Zepeda, and died in 1828, shortly after acquiring the property (Chabot 1937, p. 132). The Treviño children, María Concepción, María Jesusa, José, María Polinaria, Innocencio, Francisco José and Ramón, inherited and partitioned the property upon the death of their mother in April of 1843 (BCDR Vol. B2, p. 206-210). The center lot of this property had already been conveyed to the wife of W. B. Jaques. This property now comprises NCB 120.

Immediately to the north of the Treviño property was a tract granted to Christoval de los Santos Coy, the first school master for the villa, who was the second husband of María Curbello. María was one of the original Canary Islanders who arrived in San Antonio in 1734 to found the first Spanish civil settlement in Texas. She was born in Lancerote and died in 1803, the last of the original settlers (Chabot 1937, pp. 155, 169). Christoval sold the property to Joseph Manuel de Santa Maria, a merchant, in December of 1758 (Chabot 1937, p. 178; BCA-SA, Vol. 3, p. 231). The following year, he sold the property to Colonel Diego Ortiz y Parrilla (BCA-SA, Headrights Vol. S, p. 49). Diego Ortiz Parrilla was an important military figure throughout the Spanish borderlands, first commandant of San Luis de las Amarillas Presidio ( also known as San Sabá Presidio), and was in command when the mission was attacked and destroyed. He probably purchased the property while he was in the San Antonio area planning a campaign, to preserve Spanish prestige, against the Comanches and Witchitas. Parrilla attacked a large Wichita village on the Red River in 1759. The attack was a failure. After his unsuccessful attempts to subdue the enemy he traveled to Mexico to explain his defeat and was not allowed to return, but was reassigned to Florida (R. S. Weddle, "Diego Ortiz Parrilla," Vol. 4, pp. 1171-72, in Tyler:1996).

In 1807, the Alcalde of San Fernando de Bexar conveyed the property to Felipe Enrique Neri, Baron de Bastrop (BCA-SA, Vol. 2, p. 160). The self-styled baron was born Philip Hendrik Nering Bögel, in Dutch Guiana, on November 23, 1759. After moving to 


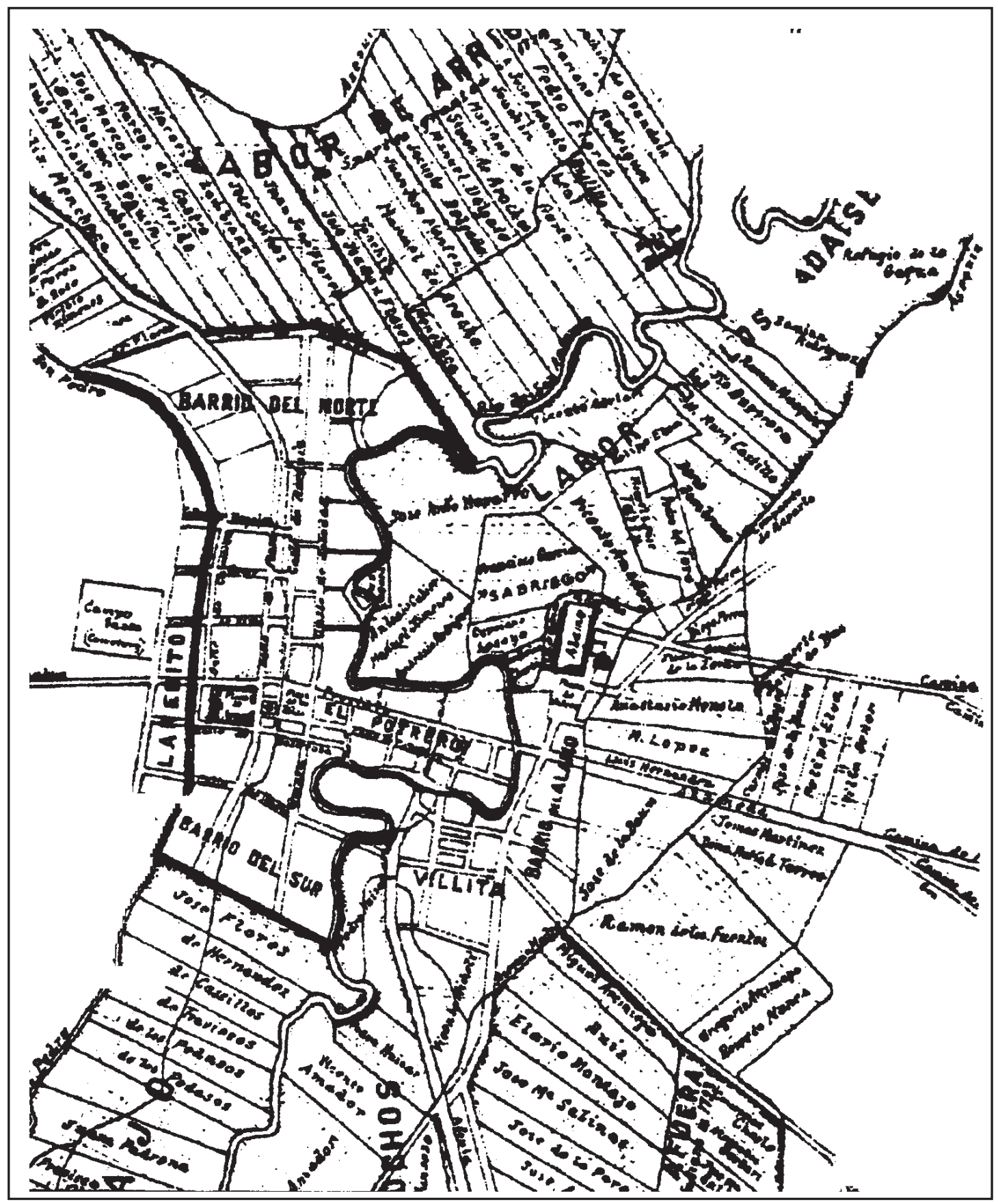

Figure 3. Early land ownership of San Antonio.

Holland in 1764, he enlisted in the cavalry and became a collector general of taxes. In 1793, accused of embezzlement, he fled the country and arrived in Spanish Louisiana in 1795, engaging in several business ventures in Louisiana and Kentucky until the territory was sold to the United States in 1803 . He relocated to Spanish Texas where he established a colony between
Bexar and the Trinity River. In 1806, he settled in San Antonio and acquired several properties. After an illustrious career with the Spanish, Mexican governments as well as the Republic of Texas, he died on February 23, 1827 (R. W. Moore, "Baron de Bastrop," Vol. 1, p. 410. In Tyler 1996). After his death in 1841 , the southern portion of this property was 
acquired by Robert K. Barrow (BCDR Vol. B1, p. 154). In 1851, the lot at the corner of Soledad and Salinas streets was purchased by Franklin L. Paschal (BCDR, Vol. J2, p. 555).

Farther to the north the property at the rincón, or the plot of land near the curve of the river that would later become Auditorium Circle, was conveyed by the Spanish government to Juan José María Erasmo Seguín (BCA-SA, Vol. 3, p. 7). Erasmo Seguín was a prominent political figure, postmaster, and businessman in San Antonio. Born May 26, 1782, he held several political offices in the City and was the father of Juan Nepomuceno Seguín, an important military and political figure of the Texas Revolution (J. F. de la Teja, "Juan José María Erasmo Seguín," Vol. 5, pp. 965-66, in Tyler:1996). Seguín sold the property to Ludovic Colquhoun, a noted military man and legislator in the Republic of Texas and official during the Confederacy, in December of 1842 (BCDR, Vol. D2, p. 137). He then conveyed the property to John M. Odin (BCDR, Vol. A2, p. 336). Jean Marie Odin, was born in 1800 in the department of HauteLoire, France, and entered the priesthood. He rose to be the first Catholic bishop of Galveston and second archbishop of New Orleans (P. Foley, "Jean Marie Odin," Vol. 4, p. 1111, in Tyler:1996). While bishop of Galveston he requested that the Ursuline Convent of New Orleans establish a Catholic girls' school in San Antonio. Seven Ursuline Sisters from New Orleans and Galveston, headed by Sister St. Marie Trouard, arrived in San Antonio on September 14, 1851, and the bishop conveyed the property to the order (BCDR, Vol. L2, p. 29).

\section{The Jaques Home}

The lot beginning 58.33 feet from the northeast corner of Soledad and West Houston streets was the site of the second home of William Budd Jaques, merchant and San Antonio alderman (Figure 4). Jaques was born in New Jersey about 1799. He moved to Mexico, where he lived for a number of years and operated a stagecoach which ran between Mexico City and Vera Cruz. In February of 1838, Jaques brought merchandise to Texas for the firm of Jaques and Browning of Grand Gulf, Mississippi, and with his wife, the former
Catherine Louise Browne, and two daughters settled in San Antonio. His home was burned when Rafael Vásquez invaded in the Spring of 1842, and he was captured by Adrián Woll's men and held prisoner until released at the insistence of Mexican officers who knew him from his days in Mexico ("William Budd Jaques," Vol. 3, p. 910 in Tyler 1996). This site was purchased by Catherine Jaques from Francisco Treviño in February of 1842 to replace their home (BCDR Vol. B2, p. 219). In 1845, and, again, in 1865 Jaques was an alderman in San Antonio. Catherine Jaques owned a boarding house on Commerce Street and died in 1866 of cholera contracted while treating victims of the epidemic. After the death of his wife, Jaques retired to his ranch on the Medina River, where he lived until his death, on September 15, 1870. He was buried in San Fernando Cemetery (Chabot 1937, p. 289-90). The structure can be seen as 304 Soledad on the 1896 Sanborn Insurance Map (Figure 4). The home was razed for the construction of the MaverickClarke Printing Company on Soledad Street about 1900.

\section{The Paschal Home}

The lot formerly on the northeast corner of Salinas and Soledad streets (now the parking garage for the Weston Center) was the former Paschal homestead, constructed in 1851. Franklin Lafayette Paschal was born at Lexington, Georgia, on January 15, 1810, the son of George Washington and Agnes (Brewer) Paschal. He arrived in Texas from Rome, Georgia, as second lieutenant of Capt. Gustavus A. Parker's company volunteers on January 12, 1836, to assist in the Texas Revolution. In December, he enlisted as a private in Capt. Clark L. Owen's Company A of Col. Joseph H. D. Rogers's First Regiment, Permanent Volunteers, of the Army of the Republic of Texas. Later, as a member of the Texas Rangers under Capt. John Coffee Hays, Paschal seriously wounded while on a scouting mission near San Antonio went to Georgia for medical treatment. In 1939, he returned to Texas and settled in San Antonio, where, by July of 1840, he owned several thousand acres of land. On February 1,1841 , he was elected Bexar county coroner. He was elected sheriff in 1843 , but resigned and ran successfully for the House of Representatives, where he represented Bexar County in the Eighth Legislature 


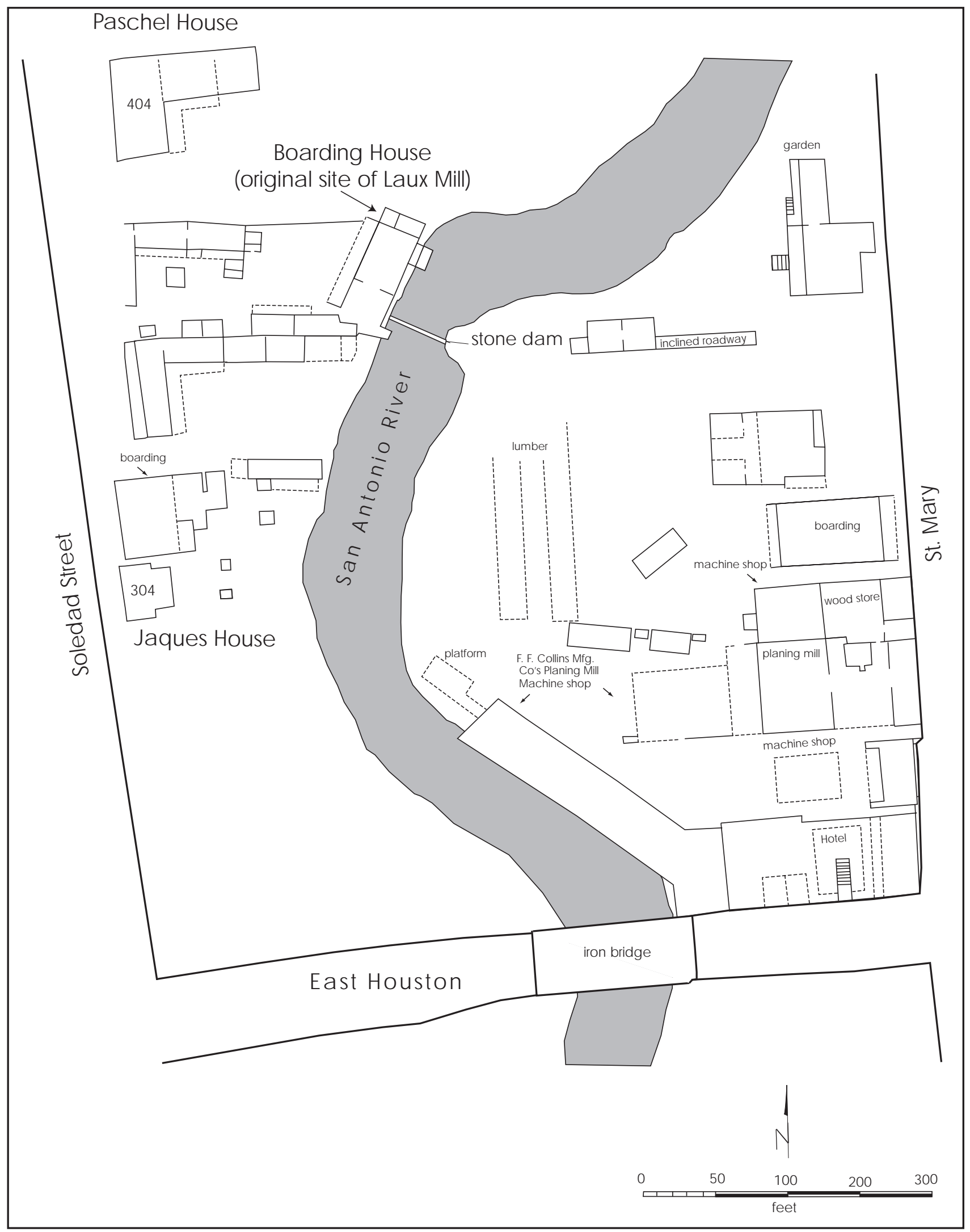

Figure 4. Adaptation of 1896 Sanborn map showing Jaques House, Paschal House, and the original location of the Laux Mill. 
(1843-44) of the Republic of Texas. He also served on the San Antonio City council, as City tax collector, and as crier of the United States district and circuit courts. On May 13, 1844, Paschal married Mary Frances Roach of Charleston, South Carolina. They were the parents of George Paschal, a San Antonio district attorney and mayor, and of physician Frank Paschal. Mary Paschal died in 1869, and Frank Paschal died of pneumonia in San Antonio on February 13, 1884 (T. W. Cutrer, "Franklin Lafayette Paschal," Vol. 5, p. 79, in Tyler 1996). The Paschal home appears on the 1896 Sanborn Insurance Map as 404 Soledad (Figure 4). This home was destroyed by the work conducted to extend West Pecan Street and the construction of the Pecan Street bridge in 1911 (San Antonio Light [SAL] February 22, 1911).

\section{Laux Mill}

In 1859, Bexar county selected the old Treviño property on Soledad Street as the site of the new courthouse. The property was purchased and the stone for the new structure selected and delivered, but the site chosen was rejected and a new location, one block to the south, was then selected (BCDR Vol. H2, pp. 158, 414, 415; R1, p. 559). In March 1866, the sheriff was ordered to place the surplus property "with the stone work thereon" at public auction and sell it to the highest bidder. Jacob Laux bid the sum of $\$ 5,100$ and received title to the property (BCDR Vol. U1, p. 26). Laux, a native of Germany, came to Texas in 1844, and settled in Salado, between Waco and Austin.

Laux moved to San Antonio (Pease, n.d.), shortly after his purchase of the Treviño property, and constructed the first flour mill in the City, all other mills, at that time, were grist mills. Laux and his sons operated the flour mill and resided in a home on the same lot facing Soledad Street (Figure 4). In July of 1873, Laux leased the mill to the firm of Alexander and Sauer, composed of Robert B. Alexander, David M. Anderson, Charles L. Sauer, and Elisha Warrenall, but the arrangement proved unsatisfactory to one or both parties and was terminated by the end of the year (BCDR, Vol. W2, p.512, 2:233). Three years later, Jacob, 60 years old and ready to retire, leased the mill to his eldest son,
Jacob, Jr., (BCDR, Vol. 4, p. 343). In 1882, the City Directory description reads:

Passing down the river by other undeveloped sites for manufacturing enterprises, we next come to the Laux mill. This is a five-story structure, with ample machinery, which can be driven by either water power or steam. The water power is communicated to the machinery by a large undershot iron water wheel of about twelve-horse power. While the steam engine now in use is of about forty-horse power. The capacity of the mill is from twelve to fourteen bushels of flour per hour, besides corn meal, mill feed and hominy. The mill is now run by Mr. Louis Seckel, late of Little Rock, Arkansas, and is situated on the bank of the river a little back from Soledad Street. (San Antonio City Directory, 1881-1882, p. 28).

Louis Seckel was Jacob's son-in-law, married to his daughter Emma, who later became a commercial merchant with the firm of J. Rouse and L. Seckel (City Directory 1883-84, Bexar County Probate Records [BCPR] File No. 6733). By 1883, the mill was leased to Joseph Landa and was no longer in operation (City Directory 1883-84). Jacob died on June 28, 1888, at age 72 , leaving his widow, Christine, with debts totaling almost \$8,000 (BCPR, Jacob Laux, File No. 1645, SAE, June 28, 1888). Christine continued to reside at the homestead and converted the mill to a boarding house (Figure 4). By 1892, she was living in the old mill and renting out the homestead (City Directory 1892-93). She continued to live in the mill boarding house until her death in May of 1913, at the age of 84 (San Antonio Light [SAL], May 14, 1913, p. 2 ). Her will reflects that she took a great deal of pride in the fact that all of her husbands debts had been paid (BCPR File no. 6733). Her daughter, Carrie Neubauer, moved into the mill and resided there until 1920 (City Directories 1914-1919). By 1920, the lot had been converted to commercial use and the structure was destroyed by the construction of the Milam Building in 1927 (City Directories 1920-1927). This was the world's first completely air-conditioned office building and San Antonio's tallest structure when it opened in January of 1928 (SAE, January 28, 1957, p. 16a). 


\section{The Ursuline Academy}

Within two months of the arrival of the Ursuline Sisters, the academy opened for classes and became the second girls' school operating in Texas. The convent, begun in 1851, is the oldest surviving pisé de terre (rammed earth) structure in the state and was designed by architect Jules Poinsard. The complex of buildings added in the middle of the century were designed by François Giraud, who also designed St. Mary's Church and the renovations to the San Fernando Cathedral. He served as City engineer and mayor from 1872 to 1875. The complex, as completed by Giraud, appears on the 1896 Sanborn Insurance Map (Figure 5).

\section{Houston Street Bridge}

Until 1851, Houston Street did not extend beyond the east bank of the San Antonio River. The unpaved lane was known as Calle Paseo. "Generally citizens with good reason referred to it as 'Paseo Hondo' which freely translated, meant ditch or deep gully. In rainy weather the unkempt street became a virtual river that drained all the land east of Travis Park and north of Alamo Street" (Steinfeldt 1978, p. 66). In 1851, a new wooden bridge was constructed across the San Antonio River that connected Paseo with Rivas Street on the west side, and the road became known as Houston Street. With the need for frequent repairs, the old

In 1910, a new academic building was constructed which burned in 1967. In 1969 , the complex was placed on the National Register of Historic Places (Sister I Miller OSU, "Ursuline Academy, San Antonio," Vol. 6, pp. 680-81, in Tyler 1996).

The cemetery was located beyond the laundry building and was entered by a narrow wicket gate and enclosed by the bend in the river. It was described by Emily Edwards as "almost covered over with white marble stones and with low mounds below tall black crosses." (Edwards 1981, pp. 17, 19). It appears that the area occupied by the cemetery was covered by the extension of Oakland Street (now North St. Mary's Street) and the one-story building to the east at 720-722 North St. Mary's (Jones 1983, fig. 1). By 1961, the academy had outgrown the campus and a new campus on Vance Jackson Road was begun. The San Antonio Conservation Society undertook immediate action to acquire the complex and restore the buildings. After an extensive expenditure of money and effort, a new tenant, the Southwest Craft Center, occupied the complex in 1975 (Fisher 1996, pp. 388-395).

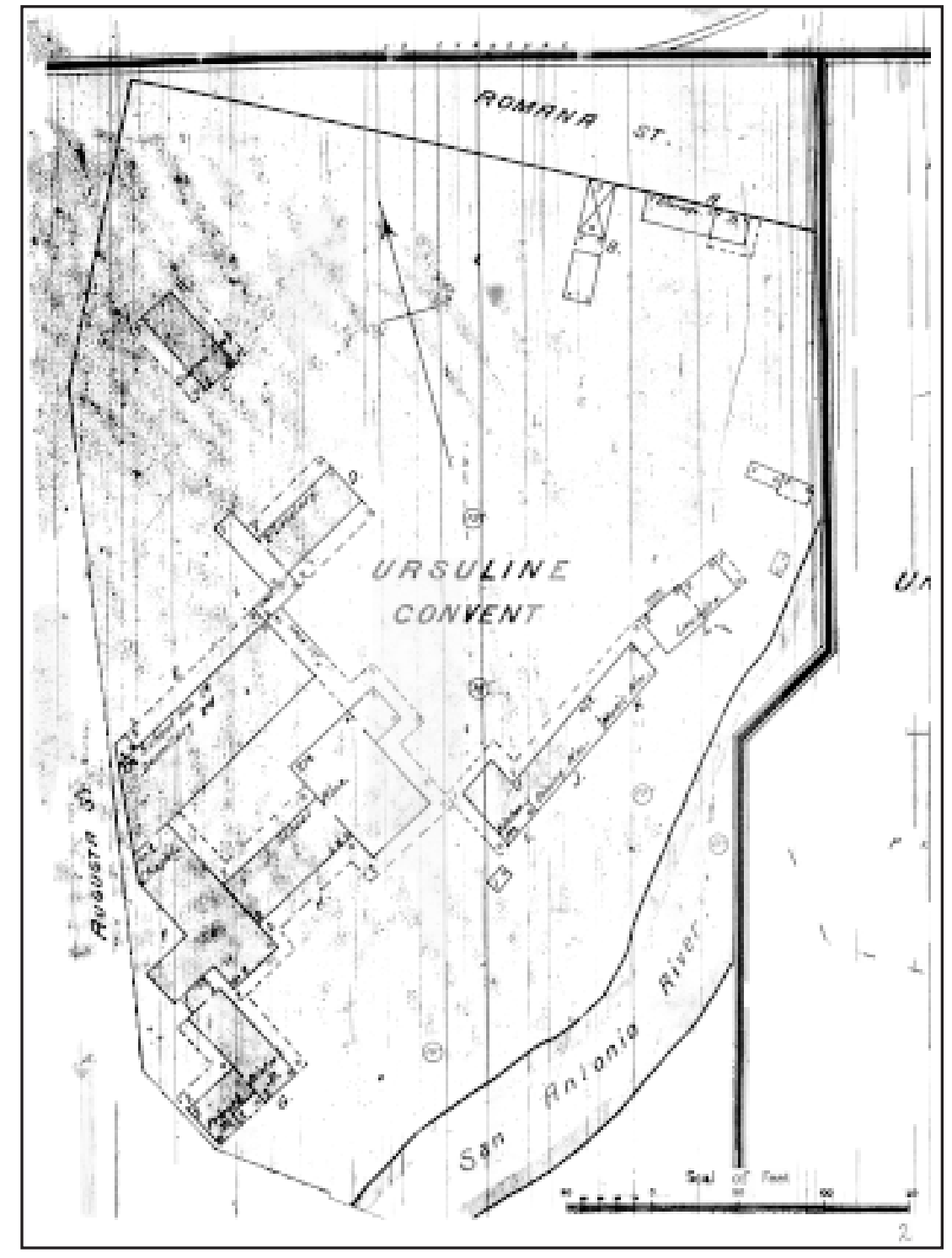

Figure 5. The Ursuline Academy. 
wooden structure still remained until April of 1914, when City council authorized the City clerk to advertise for bids on "concrete bridges over Houston and Commerce Streets" (CJM-Book W, 1912-1914, April 13, 1914, p. 242). Council records reflect that the "bid for the construction of a concrete bridge over the San Antonio river over Houston street by Jones and Day, dated May 25, 1914 accepted by council 13th of November 1914" at a cost of \$16,400 (CJM-Book X, 1914-1915, p. 184). Houston Street bridge is the only bridge in the study area that does not bear an information plaque.

\section{Augusta Street Bridge}

On December 16, 1889, City council began considering iron bridges, primarily for the South St. Mary's and Market Street crossings of the river in the downtown area. There were already iron bridges on Houston and Commerce streets (CJM 1888-1890, Book H, p. 567). On February 27, the proposals of several bridge companies were presented to council. The presentation by the Berlin Bridge Company of Connecticut was evaluated in this manner: "The bridge presented by the Berlin Bridge and Iron Co. is a parabolic arch truss bridge, with or without overhead bracing, similar to the Commerce street bridge, but stronger and more rigid. This type of bridge is considered one of the best now in use. \$37,929.00 (Report of Paul Pretzer, City Engineer," Book H, p. 684). This company was selected to supply the City with several bridges, including the Augusta Street bridge, one of only two which still exist in their original locations. "The graceful thick arches were complemented by four churchlike spires serving as endposts... All were customized to allow parade floats to drift by undeterred." (San Antonio Express-News [SAEN], June 26, 1995).

\section{Collins Manufacturing Company}

The old Rodríguez grant of the Alamo land, now NCB 403, was described shortly after the Civil War by Vinton Lee James' narrative of the City as "a large vacant lot, and afterwards, in 1885, F. F. Collins had his machine and windmill shop there" (James 1938, p. 96). Actually, Finis Collins did not purchase the property until March 26, 1890, and the City directories indicate that the business was not established until 1891 (BCDR Vol. 65, p. 88; City Directory 1891). Listings for the business indicate that it provided "windmills, horse power, pumping jacks, tanks, iron pipe and filters, steam and brass goods, and water supply materials; also repairing of machinery" (City Directory 1901-01). In 1907, Collins turned the business over to James M. Morlan and E. J. Algelt and it became the CollinsGuether Company, specializing in digging machinery. He retired to his "Collins Farms" located three miles south of the City (City Directory 1907-08). By the following year, 1908, the digging machinery business had been closed and the old office structure was occupied by the Riverside Restaurant (City Directory 1908, 1913).

In 1926, the lot was cleared and the Texas Theater was constructed. A 3,000 seat Spanish revival-style structure, it was one of 127 movie palaces designed by the Kansas City firm of Robert Otto Boller. In 1927, the theater hosted the first major motion picture premier ever staged outside of Los Angeles or New York. Wings, a movie that was filmed in San Antonio, won the first Academy Award given for best picture (Fisher 1996 pp. 92). The Texas Theater was an addition to the Majestic, Empire, Aztec and Princess complex of elaborate showplaces located in the downtown area.

In 1974, the declining structure was purchased by the Bexar County National Bank, completing its acquisition of the entire parcel bounded by Houston, St. Mary's, Travis, and Soledad streets. In 1978, the bank was acquired by Republic Bank of Dallas, which set forth a plan for a one million square-foot, $\$ 125$ million Republic of Texas Plaza on the site. The San Antonio Conservation Society immediately expressed concern and opposition to the demolition. The Historic Review Board denied the bank's application for a demolition permit and the bank countered by seeking a City council override of the denial. Conservation Society directors asked for an injunction to block demolition. The result was an Agreed Temporary Order, signed with Mayor Henry Cisneros acting as mediator. The bank agreed not to begin demolition for sixty days while the Conservation Society developed an alternate plan. The Conservation Society contracted architect Alex Caragonne of Rayna/Caragonne Architects, in collaboration with Princeton University's 
noted post-modern architect Michael Graves. The plan Graves devised was described by one observer as "a Beaux Art vision of a Mesopotamian palace" (Fisher 1996, p. 425). The finished plan, which cost the society more than $\$ 123,000$, was presented to bank officials and the public on the last day prior to the expiration of the court order. The bank rejected both the plan and the society's offer to purchase the entire block and began demolition with only the ornamental façade retained. (Fisher 1996, p. 422-426). In 1989, before the Republic of Texas Plaza could be completed, Republic Bank failed and the property was foreclosed (Fisher 1996, p. 429, SAEN, July 5, 1989).

\section{The Floods of 1913}

The City completed the extension of Travis and Pecan streets and had installed new bridges over the river at those points early in 1911 (SAL, January 27, February 22, 1911). In 1913, San Antonio and much of the state was experiencing a severe drought. At the beginning of October, finally, the drought broke. In San Antonio, torrential rainfall caused the river to rise six feet, two bridges were weakened, and outhouses and fences were washed away. The weather bureau reported 3.30 inches of rain and much of the downtown area suffered damage from high water (SAE, October 2, 1913). Yet this was only the beginning, for the rains intensified north of the City and drenched the Olmos drainage area causing a sudden rise in the San Antonio River and massive flooding from the Josephine Street bridge throughout the City. "Silently the storm water shed from the hills crept into the city. In its race to the sea the volume each minute became greater and rose higher until the narrow channel of the river burst, spilling the flood over the lowlands and into the homes of hundreds who slept unconscious of their danger." (SAE, October 2, 1913).

During the 24-hour period the City received 7.08 inches of rain. Heroic rescues performed by City police and firemen held the death toll to four, but property damage was estimated at $\$ 250,000$ for the City alone. Water rose to waist-deep throughout the entire business section, and stream flow was estimated at 7,200 cubic feet per second (SAE, October 3, 1913, Metcalf and Eddy 1920: i).
The terrible tragedy immediately evoked cries for preventative measures from the overwrought citizens. Even as the City was waiting for the waters to recede, Mayor Clifton Brown and his advisors had developed a plan to build a dam beyond Brackenridge Park in the Olmos watershed to act as a "storehouse for the flood of water resulting from incessant rains such as the city has had for the past few days." The Express expanded upon the source of the problem: "It is generally known that the flood in the San Antonio River came from another stream called the Olmos, which drains an extensive watershed. It was not the volume of water so much as the abruptness of its inflow that caused the San Antonio River to leap out of its bounds and try to spread all over everything and now that the flood has subsided where is all the surplus water?"

The paper, then, expressed concern that the river had been well below its normal limits for over a dozen years, and noted that if the flood waters could have been stockpiled the water would have served as a supplemental reserve for an extended period. "Some persons not as familiar with the vagaries of the river as the oldest inhabitants who have seen periodical floods for a half a century - nearly always following a period of very low stage-suggested that the river be covered over and made into a sewer." They, then, pointed out that this solution would be a disaster when the flood returned, and was not viable. They concluded their opinion with the cry: "Dam the Olmos!" (SAE, October 4, 1913).

The City had only begun to return to a sense of normality, when the river was swept into a second rampage on December 4 . This time the City was given ample warning of the danger, perhaps as a result of the renewed concern of the ever-present threat that the river possessed. Again, the flood was a result of widespread storms over the southern portion of the state and torrential rains in the watersheds north of the City. Although the property damage was equal to the flood of October, this time there was no loss of lives (SAE, December 5, 1913). The actual flow of water in the flood was, in fact, higher, estimated at some 8,000 cubic feet per second, but early warning and the lasting effects of the earlier flood lessened the impact (Metcalf and Eddy 1920:i). 


\section{North St. Mary's Street Bridge}

With several bridges severely damaged by the 1913 floods, the City Commissioners in October of 1914 directed the City Clerk to advertise for bids for constructing concrete bridges at several points in the City. Among these was one "across the San Antonio River along the extension of St. Mary's Street north from Travis street" (CJM, Book X, 1914-1915, p. 119, October 1914). In November, the City engineer recommended that the bid of $\$ 24,500$ from the J. H. Richardson Company be accepted (CJM, Book X, 1914-1915, p. 220, November 23, 1914). The construction of the bridge was completed and accepted on March 17, 1915 (CJM, Book X, 1914-1915, p. 764, June 28, 1915).

\section{Municipal Auditorium}

Along with electing City officials in May of 1919, the voters also passed a bond issue of $\$ 3,950,000$ for improvement of streets and sewers and the construction of a municipal auditorium. Immediately, the question of the location for the auditorium became a major issue in the City. Mayor Bell, realizing the political sensitivity of the issue and not wishing to begin his administration on the wrong foot, quickly made an announcement: "City Commissioners are not committed on the site for the proposed municipal auditorium. The matter will be left entirely to the people," (SAE, May $25,1919)$. One suggestion even included tearing down the existing City Hall and erecting a combined auditorium and municipal building on the site.

Regardless of the mayor's political hedging, the site preferred by most city authorities was at a bend of the river at Romana and Navarro streets. A local paper protested, "putting the auditorium on a site which is approximately five blocks (a quarter of a mile) from any street car line because it believes the auditorium should be accessible to all citizens, not merely to those who have automobiles or who may live within walking distance of the Romana Street site" (SAE, July 29, 1919). They, also, initiated a write-in campaign to elicit public comment. The locations submitted ranged throughout the City, with both San Pedro and Travis parks generally favored. The press soon discovered that the City government had already purchased the property in the bend of the river at the Romana-Navarro location, despite the fact- "for it may be regarded as fact- that a very large portion, if not the major portion of the $\$ 200,000$ bond-fund for widening and altering the river channel must be expended on the work of putting this riverside property in shape to receive a half-million-dollar public building; and, generally, in consideration of the fact that an auditorium so placed would neither be nor appear to the advantage of this community" (SAE, July 31, 1919). In December, the City purchased two additional tracts at the river bend for $\$ 38,250$ (SAE, December 2, 12, 1919).

Due to the flood of 1921 and resulting expenses, the construction of the auditorium was delayed for over five years. In 1925, the City also began the task of eliminating the larger curves on the San Antonio River bed. The first major channel alteration was in conjunction with the preparation of the City Auditorium site. In this case, the old loop was cut and the stream channel filled with the dirt from the excavation, forming a new street connection between Convent and Navarro streets. This created a legal problem for the City because title to creek beds and river channels by law belonged to the state. The City was required to request passage of a bill by the Texas legislature giving title of such lands to incorporated municipalities (SAE, February 1, 1925).

The Municipal Auditorium, a Spanish colonial revivalstyle structure constructed of Indiana limestone and designed by Atlee B. Ayres, was built at a cost of $\$ 1.5$ million and completed in 1926. Recognized by an award from the American Institute for Architects, it was designated as a memorial to those who served in World War I. The structure was gutted by fire on January 6 , 1979, and reopened in February of 1986 (Fisher 1996, pp. 417, 435).

\section{The 1921 Flood and River Channelization}

The disastrous floods of 1913, and the near flood of 1919, convinced City officials that action had to be taken to avert a major disaster. Some improvements had been accomplished, such as the "sea walls" constructed by the City engineer in the "Big Bend" 
area of downtown, and the restrictions that had been placed on construction along the river between Josephine and Mitchell streets. In fact, the dictatorial placement of the auditorium along the river was to a great extent a flood control measure; by using bonded river improvement funds the planning would eliminate a major bend in the river while creating the construction site, solving two problems with the single expenditure of bond revenues. Yet, all of these measures were merely partial fixes to a very complex problem. It had been obvious to those involved with the aftermath of every major flood since 1865 that a final solution entailed straightening the river and removing all impediments to the free-flow of water; but this was not an easy or popular solution. The majority of citizens were too enamored with the picturesque, winding stream to have it converted into a widened concrete canyon slashing through the heart of the City. Also, several of the major restrictions to the flow, the dams along its course, were still commercially important to local industries. It was determined that an outside agency could make a careful study of the situation and offer an unbiased evaluation.

In the spring of 1920, Commissioner Lambert was instructed to search out a firm to study the problem and produce an in-depth report to resolve future flood hazards. The commissioner contacted the firm of Metcalf and Eddy of Boston, Massachusetts, and requested an estimate for a complete study of the alternatives. The firm submitted a bid of $\$ 10,000$ to produce a report that would address both past historic floods and develop substantive solutions and cost estimates of corrective measures. On June 9, 1920, the contract was approved by the City, and the firm's chief engineer, Charles W. Sherman, immediately began a nine-day, on-site evaluation of the existing river conditions, working in conjunction with City engineer A. Marbach (Metcalf and Eddy 1920:1)

The report was both well-researched and insightful with regard to the past history of river and creek flooding and advised a realistic approach to the actions that must be taken to correct the situation. It recognized the efforts of the City, but recommended against the auditorium cut-off construction until further studies had been completed. It also addressed the necessity of removing all obstructions from the river channel, including not only both Guenther Mill dams but also the remaining structures on the upper mill complex. It suggested that the City should undertake the construction of six cuts across bends of the river in the downtown section. The first cut-off suggested was just below Josephine Street where flooding had first begun in 1913; the second cut was between 8th and 10th streets at the intersection of Oakland, Arden Grove, and 9th Street; the third was at the large bend at Trenton Street; and the fourth was suggested for the Romana Street bend where the auditorium site was planned. The two remaining cuts were suggested for the bend at Martinez Street, near what is now the Durango Street crossing, and the final cut-off was proposed to shallow the curve at the Guenther Lower Mill (now Pioneer Flour).

In addition, further river work was suggested along the "Big Bend" area, the raising of three bridges, and the adjustment of the abutments on a fourth. The overall planning factors were directed at enabling the channel to "safely carry 12,000 cubic feet per second through the heart of the city," the figure they anticipated would be required to handle the "hundred-year flood." Contrary to popular opinion, the Riverwalk bypass channel was not recommended by this study. The estimated cost of this construction was placed at $\$ 4,000,000$; that figure included $\$ 950,000$ for a detention basin on Olmos Creek. The firm acknowledged that discussions with the City government had already indicated that the expenditure of this amount of money was not considered possible due to "other urgent needs of the city." Therefore, they recommended the immediate expenditure of $\$ 2,500,000$ for what they considered the most critical needs within the period of the next five years. They concluded their study with a rather dire prediction concerning the next major flood:

"When such a flood will recur, no man can say. But that it will recur is certain. Therefore, with the rapid growth in value of property in the city, particularly in the congested value and commercial districts, it is imperative that this danger be recognized and that the work necessary to prevent serious injury from flooding be undertaken as rapidly as the financial resources of the city shall permit,

- lest when the flood comes it shall find the city unprepared and do ruinous damage" (Metcalf and Eddy 1920: ii). 
After the record rainfall of 1919 , the City entered another period of drought. In 1920, the total rainfall for the year was a mere 19.56 inches, almost ten inches below normal. The first eight months of 1921 promised no respite from the dry spell with only 17.84 inches, a full inch below normal. Finally on September 9th, there was news of a break in the drought:

"The most timely showers since 1919 have fallen over Southwest Texas in the past two days, coming just as stockmen were facing the prospect of buying feed or shipping their cattle to other pastures from the depleted range"

(SAE, September 9, 1921).

The rainfall that was beginning to break the drought in West Texas was the result of a tropical disturbance that had formed in the western Gulf of Mexico and had crossed the Mexican coast south of Tampico on September 7 . Weakening slightly after contact with the land mass, the storm took up a northeasterly direction from Mexico into Webb County. It then progressed into Bexar, Comal, Hays, and Travis counties before extending into Williamson, Bell, and Milam counties where it abruptly dissipated. In Milam County it reached the western bank of the Brazos River, but there was virtually no rainfall on the east bank or beyond.

In San Antonio a light shower of 0.53 inches occurred on September 8, as a result of the moisture from the leading edge of the air mass, but the main thrust of the storm did not reach the City until between midnight and 1 a.m. on the 9 th. At that time, steady rains began in the City and continued throughout the night. The rainfall began to intensify throughout the day and continued into the next day. The storm was manifest as an entire series of intense thunderstorms, each with driving sheets of rain and deafening thunder that passed over the town one series after the other and continued with no relief until mid-morning of the 10th (Ellsworth 1923:8-10). The actual amount of rain varied considerably within the San Antonio River basin but over eight inches was recorded within the downtown area, and over seventeen inches was reported in the upper Olmos Creek basin.
At first it appeared that the improvements to the river would be adequate to contain the deluge, for the initial level was scarcely a foot above normal, but then the "wave from the Olmos, down the valley northwest of Brackenridge Park, struck the headwaters of the river and forced it beyond its banks." So quick was the rise, more than one hundred tourists camping in Koehler Park barely had time to save their lives, and many lost their effects." Within an hour the rise had passed through the limits of the park and water was more than two feet deep on Broadway Avenue, and the river in the downtown section was near the embankments at St. Mary's Street. It was then hoped that the water had crested at the level of the 1913 flood, but within minutes the water was flowing down the street;

"in 20 minutes College Street was flooded as far as

Navarro. In 10 minutes more, it had reached the flooring of the Navarro Street bridge at

Crockett Street. By 1 o'clock it was impossible to

leave the Express Building with any assurance of safety, in a torrent sweeping east to

Presa Street. The crest of the flood apparently was reached about 1:45 o'clock when the water was between 5 and 6 feet deep on Crockett Street... and was more than 8 feet deep at Houston and St. Mary's" (SAE, September 11, 1921).

October 25, 1923, the City commission voted unanimously to present the taxpayers with a bond issue of $\$ 4,350,000$ the first week in December. Along with $\$ 2,800,000$ for the dam on the Olmos were eight other proposals: $\$ 200,000$ for the new auditorium, $\$ 100,000$ for fire and police services, $\$ 250,000$ for street, $\$ 100,000$ for bridges, $\$ 250,000$ for storm sewers, and $\$ 100,000$ for additional sanitary sewers (SAE, October 26, 1923). On the eve of the election Mayor Tobin reminded the public of the importance of the issue: "This election for flood prevention is the turning point in San Antonio's history, I hope everyone turns out and votes for greater San Antonio. If we don't vote the bonds, we don't go ahead." The experienced observers at City hall were forecasting the heaviest bond issue in history, estimating a turnout of 16,000 with a 9 to 1 majority for the bonds (SAE, December $4,1923)$. They were partially correct in their 
predictions, for the total votes counted were the largest for any bond election; however, the flood prevention bonds carried by a majority of only 1,638 of a total of 15,904 ballots cast. All other issues were approved by a majority of 3,000 or more. Mayor Tobin expressed his pleasure that the issue had passed but stated "he felt a 'little blue' that the victory was not bigger for the bond issue... I am sure that when this great work is finished, the public will be sorry that all voters were not for it all along" (SAE, December 5, 1923).

True to his promise, as soon as the money was secured Mayor Tobin charged the Citizens' Flood Prevention Advisory Committee with the task of selecting a Project engineer for the construction of the retention dam on the Olmos. It was determined that the channelization of the western creeks would begin immediately under the direction of the City engineer utilizing City crews. The preliminary work in preparation for the dam structure was also to be done with City labor; the actual construction of the retention structure, however, would be performed under contract. To direct the overall prevention program the committee interviewed a number of engineers. Many of the leading engineering firms of the southwest joined in the bidding. On Monday, August 25, the committee announced that they had decided to recommend C. F. Crecelius to oversee the project by a vote of seven to two, with four members of the committee not present for voting (SAE, August 26, 1924).

Colonel Crecelius was well qualified to perform the function. He was a graduate of Missouri State University with a degree in civil engineering, and soon was in charge of construction of Lock and Dam No. 1 on the Osage River, Missouri. In 1903-04, he had conducted a survey of the Wabash River from Vincennes, Indiana, to its mouth for the purpose of planning locks and dams which would create an eightfoot stage to prevent flooding along that river. In 1914, he had constructed an arch dam at Frankfort, Kentucky, that, at the time, was the "slenderest dam in the world", being 45 feet high, rising from an eight-foot base to two feet at the top. He had also designed the Jefferson Davis monument, an obelisk 351 feet high, second only to the Washington monument. During World War I he rose from major to colonel of engineers in 1918.
He came to Texas in 1921, where he was with the state highway department, and at the time of his recommendation was employed by the city of Laredo. He was appointed to fill the position by the City commissioners on August 30 (SAE, August 31,1924). By December 1926, the massive structure was ready for dedication to the public. The dam had a maximum height of 90 feet, a length of 1,940 feet, with an approach of 940 feet on the Alamo Heights side and 640 feet on the southwestern or Laurel Heights side. It contained 90,000 cubic yards of concrete, 418,000 pounds of reinforcing steel, and had a storage capacity of five billion gallons of water (SAE, August 28, 1926).

In March 1926, the City opened negotiations for acquiring the initial property required to excavate an overflow channel to divert the waters of the river and eliminate the danger of the flooding at the "Big Bend" district in the heart of the City. The cut was planned from the eastern turning point of the bend, north of Commerce Street and west of St. Mary's. It would then progress south through the area previously occupied by the old Market House, cutting the river again to the east of the second bend that formed Bowen's Island, thus eliminating that bend and returning to the channel north of Nueva Street. The land was acquired the following week for $\$ 50,000$ cash.

Other parcels of land were required for the project, but no other buildings were involved at that time (SAE, March 16, 1926). In June, however, the City commission appropriated $\$ 175,000$ out of the flood prevention fund to acquire other property. The old French Building, built in 1855, at the corner of Main Plaza and Dolorosa Street, was purchased for $\$ 65,000$, and the old Market house, fronting on Market Street, was purchased from a syndicate which had acquired the property from the City about a year previously. For that property the City paid $\$ 27,463.76$, which is what the syndicate of Oppenheimer, Clegg, Herff, and Groos had paid for it plus 8 percent (SAE, June 15, 1926).

In June 1929, Mayor Chambers was presented with another plan for the beautification of the river. This scheme, submitted by Robert H. H. Hugman, concerned the "Big Bend" area and proposed to "divert all water of the river up to a certain level into the new 
flood channel and permit construction of walks and Spanish-type architecture along the banks of the stream" (SAE, June 27, 1929). In reality, the Hugman plan was far more visionary and complex. His vision would create a "miniature Old World Street" along the river lined with "shops of Aragon and Romula." He envisioned Aragon as shops with flowering vines and trees along a cobblestone street between Houston Street and the City Public Service Building. Romula would extend along both banks of the river from that point around the remainder of the bend to the end of the cut-off channel at Villita and Dwyer streets. His dream was populated with shops, artists' quarters, cafes, and apartments at the rear of all the present buildings (SAE, June 29, 1929).

As these plans were under consideration, a City plan committee, consisting of 52 prominent citizens representing all sections of the City, appointed by the mayor six months previously, presented its report to the commission. They proposed that the City expend $\$ 40,000$ and hire Harland Bartholomew, city planning expert of St. Louis, to "conduct a survey of San Antonio and definitely work out a modern plan of growth for the city." Of that sum $\$ 4,000$ would be Bartholomew's salary and the remainder would "be used for the force of technical and clerical workers and other attendant expenditures over a period of from two to two and a half years."

The chairman of the committee, N. H. White, presented a "concerted attack" upon a counterproposal by Hugman to present prizes of $\$ 5,000$ and $\$ 2,000$ for City plan ideas in a national competition. Hugman argued that a professional city planner might "destroy much of the individuality, the spirit and charm of old San Antonio." White characterized Hugman's idea as an "idle dream" and maintained that the competition would "set back a city plan for San Antonio six months by going over ground already covered by the committee." He insisted that Bartholomew was interested in preserving the individuality of the City, for this was the first thing noticed and commented upon. White further argued that "competitions have proved a failure, any how, the Conservation Society has tried that, offering $\$ 500$ for the past two years, and nothing has been accomplished" (SAE, July 16, 1929).
The following Thursday, the proposal was officially presented to the commissioners. Samuel Smith and Jack Beretta advocated employment of local engineering, architectural, and landscaping experts to develop a plan for the City, hiring Bartholomew as an advisor. Raymond Phelps, a local architect, and D. D. Harrigan, engineer, were suggested as local talent, due to their success in developing the new Cavaliers' Saddle Club facilities. Commissioner Wright challenged Beretta's example as "comparing a mosquito to an American eagle" in light of developing a plan "for a city destined to have within a few years 500,000 population." Phelps interjected that "he had studied city planning just long enough to ascertain that it was an expert's job and that he himself would never make a city planner." The commissioners adopted the recommendation of the City plan committee (SAE, July 19, 1929).

Soon there arose another problem with the flow of the river. The engineers at Hawley \& Freese informed the commissioners that the Travis Street bridge might need to be destroyed. Their survey revealed that the thick cement arches supporting the bridge could, in times of flood, back up the water, cause drift jams and narrow the channel creating a menace to the City. The Travis Street bridge, constructed in 1911 at a cost of $\$ 15,000$, differed in construction from most of the bridges. Replacement cost was estimated at $\$ 30,000$ (SAE, July 13, 1929). Commissioner Paul Steffler declared that the initial report on the bridge was too technical and demanded a second survey (SAE, July 19, 1929).

The new survey, not completed until September, revealed that the bridge over West Martin was far more of a hazard to stream flow than any of the others. It revealed that both it and the Romana Street bridge were greater impediments than the Travis Street bridge, which the City was asking for bids on redesigning. The Martin Street bridge had a capacity of only 8,120 cubic feet of water per second, the Romana Street bridge had 8,200, and the Travis Street bridge 8,440. By contrast the new "Big Bend" cut-off was designed to have a capacity of 26,000 cubic feet per second (SAE, September 6, 1929). The rock from the French Building had been saved and was used to construct the walls of the river channel from Travis Street to the 
Municipal Auditorium (Fisher 1996: 185; SAE, April 6, 1927).

In February of 1929 , the City was finally able to advertise for bids on the "Big Bend" river channelization. Bids received ranged from $\$ 153,265.87$ to $\$ 178,970.96$. The high bid was submitted from Kroeger-Brooks Company, the lowest from Bart Moore, Inc., a local firm. Others bidding were McCrary Construction of Atlanta, GA, Sumner-Sollitt Company, J. DePuy, Sexton Corporation, Walsh and Burney, and the McKenzie Company. All bids were under the cost estimated by the engineers, Hawley \& Freese, by $\$ 50,000$ (SAE, February 19, March 12, 1929). The work was to consist of construction of the 70 -foot channel, removal of 15 feet from the new public health and detective building at Dwyer Avenue, and bridges at Market and Commerce streets (SAE, March 20, 1929).

On February 1, 1930, Moore completed the work on the cut-off and turned the project over to the City; on March 17, the City commissioners officially accepted the work and issued a check to the company for $\$ 25,000$ for the cut-off, plus $\$ 305.91$ for extra work required that was not covered by the initial contract (SAE, March 18, 1930). The portion of the river at the southern end of the "Big Bend" was equipped with a seven-foot dam because the level of the channel was below grade, creating a long water-filled pool to Commerce Street (SAE, April 27, 1930).

\section{Romana Street Bridge (Navarro)}

In December of 1920, City council took action to construct a new bridge over the proposed river bed that was to be filled for the Municipal Auditorium. Plans were drawn up by the engineering firm of Bartlett and Ranney (Minutes of Commissioner's ProceedingsBook D, 1919-1921, p. 395-December 30, 1920). On January 20, 1921, the council voted to accept the proposal of McKenzie Construction Company (Ordinance MD-1065, full text in Street Improvements Records, Vol. 8, p. 230).

\section{Lexington Avenue Bridge (Fourth Street)}

In December of 1920, City council authorized the City clerk to advertise for bids for taking down the existing steel span and for the construction of a reinforced concrete bridge on 4th Street over the San Antonio River (Minutes of Commissioners' ProceedingsBook G, 1925-1927, p. 153-December 14, 1925). After the bids were received, the proposal of Pryor \& Jefferson was accepted. (Minutes of Commissioners' Proceedings, p. 287-January 25, 1926; full text of ordinance in Street Improvements Records, Vol. 15, p. 47).

\section{Martin Street and Pecan Street Bridges}

Prior to the construction of the Pecan Street bridge in 1911, there was a foot-bridge nearby dating from at least the mid-nineteenth century. Apparently, the footbridge coexisted with the 1911 West Pecan Street bridge, for in March 1914, the council voted to have the "foot bridge over West Pecan restored." (CJM, Book X, 1914-1915, p. 78). Funding for both the Martin and Pecan Street bridges was approved at the same time by council. Bids were advertised on February 14, 1927, and the proposal of Pryor and Jefferey was accepted on March 22 (Minutes of Commissioners' Proceedings-Book G, 1925-1927, pp. 529, 577; full text in Street Improvements Records, Vol. 16, p. 657).

\section{Travis Street Bridge}

The original Travis Street bridge installed during the street extension in 1911 was not compatible with the new design for the river channelization. It was ordered replaced -as recommended in the report filed by the City engineer- in reference to construction and improvements to Travis Street with attached documents (Minutes of Commissioners' ProceedingsBook H, 1927-1928, p. 306; for full report see Street Improvement Record Vol. 18, p. 424, January 16, 1928). 


\section{Convent Street Bridge}

In March of 1929, the commissioners approved City Ordinance 666, which authorized the expenditure of $\$ 35,000$ for a concrete bridge over the San Antonio River at Convent Street (Minutes of Commissioners' Proceedings-Book I, p. 352-March 25, 1929). In May, the proposal of J. G. Jefferey for constructing a reinforced concrete bridge over the San Antonio River on Convent Street was accepted (Minutes of Commissioners' Proceedings-Book I, p. 437; full text in Street Improvements Records, Vol. 20, p. 347).

\section{Richmond Street Bridge}

In August 1929, the commissioners authorized the City clerk to advertise for bids on the last of the bridges in the study area, the specifications called for a "concrete and steel plate girder bridge over the San Antonio river on Richmond Avenue extension" (Minutes of Commissioners' Proceedings, Book I, 1929, p. 498June 17, 1929). The bridge was completed the following year.

\section{River Beautification}

The beautification of the City's little river had long been a recurring dream of visionaries who realized its potential for attracting tourists to San Antonio. However, it took a man of imagination and specific training like Robert Hugman to develop these ideas into concrete plans. After his graduation from the University of Texas School of architecture in 1925, he married and located in New Orleans where he began his practice. By his own admission, it was during his three years in that city that he became impressed with their preservation of the Vieux Carré, and "the old world charm, beauty, local color and character of it all" (Hugman 1968:3). Upon his return to his hometown, in 1929, he attempted to transfer these qualities to the waterway of San Antonio. This was, of course, the time of massive alterations of the stream for flood control and there were fears that the downtown sector might be lost. Through the encouragement of the Conservation Society, Hugman was able to present his vision to about 100 of the City's prominent people who endorsed development for future planning on the river. Despite their support, there were only funds for flood prevention, his dream of development and beautification had to be shelved.

In April 1935, Congress passed legislation approving an expenditure of $\$ 5$ billion to support the Works Progress Administration (WPA). Administered by Harry Hopkins, it was to create employment for over two million workers in the following five year span. San Antonio, like cities all over the country, began to search for ways to use the government funds available.

The Alamo chapter of the Daughters of the American Revolution (DAR) voted to direct their efforts for the upcoming Texas Centennial toward the beautification of the San Antonio River. The parks commissioner, Rubiloa, was approached by Mrs. Edward Leighton, chairman of the committee, to request support for the project. However, when an inspection of the river determined the extent of neglect, the DAR deemed the job was so large outside help would have to be sought (the City's contribution was limited primarily to sympathy). "But, the committee found on another tour of the river Tuesday that weeds are getting taller, grass more prolific and refuse dumped into the stream is accumulating so heavily in places that the flow of water has become clogged" (SAE, August 14, 1935). The use of relief labor from the WPA was then sought.

Robert H. H. Hugman, again, presented his design for the beautification, first proposed in 1929, to the DAR committee.

"We have a priceless beauty spot in our river and could easily make it so that homes and even business places would be remodeled to face the river instead of turning their back doors toward it.

The plan drawn up proposes to build stairways down to the river bank in the downtown section, and to place benches there for the use of the public. The natural beauty could be enhanced by planting flowers and shrubbery" (SAE, October 1, 1935).

Hugman suggested that $\$ 1,000,000$ be applied for from WPA, with the added benefits of flood and malaria control being achieved. Although, supportive of his concept, the 
price was considered too great and the time too short to coordinate the massive project with the centennial; instead, an alternate plan for improvement and beautification financed by $\$ 730,000$ from WPA was undertaken. On January 8, 1936, at Concepción Park some of the river's flow was diverted into the old section of the channel to "eliminate accumulation of stagnate, mosquito-breeding pools" (SAE, January 8, 1936).

In 1936, when Robert Hugman was introduced to Jack White, it was the perfect blending of personalities, the dreamer and the developer. White had begun his career, in 1908, as a night clerk for a small hotel in Weatherford, Texas. He had learned every aspect of the hotel business-from potato-peeling in the kitchen, serving as a steward on a dining car, and finally management. By the time he was approached by Hugman, he had two hotels in his chain, the Plaza Hotels in San Antonio and Corpus Christi. Years earlier he realized the potential of San Antonio as a convention city and had organized the San Antonio Convention Bureau. The success of the Venetian Night fête for Fiesta in 1936 convinced White and others that the river truly held the key for the future of San Antonio; he now embraced Hugman's total concept for the development of the downtown section of the river. "The banks would be beautified, and unsightly back entrances of stores and shops would be transformed into front entrances, so that people could alight from a gondola to do their shopping. Benches, walks and an adequate lighting system are included in the plan. Curio stores, riverside cafes and Mexican shops would add to the beauty and interest. Troubadours would serenade, adding gaiety and color" (SAE, August 1, 1937).

In January 1938, in order to implement plans, White organized all those owners located along the river in the "Big Bend" area into a "property owners" committee" and hired Robert Hugman as their architect. In addition, the WPA District 10 administrator, Ed Arneson, resigned his position with the government to return to private practice, and was hired as consulting engineer for the river project. The members of the committee consisted of most of the downtown leaders: Judge Claude V. Birkhead, Dr. F. G. Oppenheimer, L. B. Clegg, L. J. Hart, L. G. Seeligson, Father Rabe and Father Arnold, Issac Bledsoe, D. A. Powell, J. H. Turner, I. Brenner, Jack K. Berretta, and Judge C. A.
Goeth. "The committee believes that the river can be made the outstanding beauty spot of the country." They pointed out that other cities might have beautiful parks, great zoos, magnificent stadiums, and other attractions, but with the beautification the City would have a totally unique attraction.

One aspect of the design called for a theater behind the Water Plant on Market Street with seating on the opposite side of the river, allowing for a downward spray of water to serve as a curtain between acts. The area was to be designated a street to convey its incorporation into the fabric of the downtown area. "It would attract unlimited publicity to the city from newspapers, magazines, news reels and other mediums. A boat ride on the San Antonio River would attract tourists to this city as the gondolas do to Venice" (SAE, April 24, 1938). Hugman and Arneson had computed the cost of this effort at approximately $\$ 265,000$, of which the City would have to contribute $\$ 50,000$ and the remainder could be sought from the WPA program. Armed with this proposal, White and the committee approached Mayor Quin and the commissioners for their support. The meeting, held behind closed doors, lasted over an hour with the result that the proposal was rejected. Although in favor of the goals, the commissioners were committed to cutting the budget of the City by $\$ 500,000$ and "was therefore rejecting all new projects throughout the next fiscal year, beginning June 1" (SAE, April 29, 1938). If the plan was to proceed other funding would have to be sought. White then turned to the San Antonio Hotel Association for their support, announcing that the property owners with river frontage had been asked to contribute $\$ 2.50$ per foot of frontage to support the effort. "In the open forum that followed White's talk, members said they believed the beautification would mean more to San Antonio than any other project that could be undertaken" (SAE, June 7, 1938).

White and the Chamber of Commerce assessed the situation and determined that the proper method of procuring the money would be through a bond issue, which would establish a Bonded District consisting of a block of property on each side of the section of the river scheduled for improvement. Examination of the law revealed that in order to be eligible to vote property owners must reside within the district. In the area, only five people who owned property resided in the district, 
and two were opposed to the project. After this snag, the planning committee was forced to develop a different strategy. A scheme was devised to have all of the people living in the Plaza Hotel declared property owners, therefore, eligible voters; the reasoning being if they owned personal property, even a pocket watch, they were technically qualified voters (Hugman 1968:7). When the ballots were counted, the issue passed by a count of 74 for, and 2 against (SAE, October 26, 1938).

With this "overwhelming yes vote" the beautification committee asked Mayor Quin to seek the services of Conrad L. Wirth, technical advisor of the National Park Service, to assist in securing the WPA grant for the remaining capital investment required. White, also, announced that the committee was planning to convene in early November to draft final recommendations to be presented to the City commissioners for "ordinances regulating boat traffic on the improved stream" (SAE, October 27, 1938). On November 3rd, the City called for bids from investors for the beautification bonds, anticipating the immediate approval of the bond issue by the state (SAE, November 3, 1938). The first bid received was from the combined firms of BrownCrummer Investment Company and the Van H. Howard Company at an interest rate of 3.5 percent on a thirty-year issue and offering a $\$ 50$ premium. The second bid was from the combination of Dewar, Robertson and Pancoast and Mahan, Dittmar and Company, who offered an interest rate of 3.75 percent with a premium of $\$ 1.50$ (SAE, November 4,1938 ). The following week the Brown-Crummer and Howard bid was revised by raising the premium to $\$ 1,500$ and the cost item to $\$ 1,800$, reducing the difference to be paid by the City to only $\$ 300$. No change was made to the 3.5 percent interest rate. These modifications were made to comply with WPA requirements to insure the approval of the additional $\$ 300,000$ of government investment (SAE, November 11, 1938). As soon as the bonds were printed, Jack White and the City treasurer personally delivered them to Austin (SAE, December 1, 1938).

With federal funds secured the planners could definitely see that the project was to become reality at last. The concept was one designed to excite the imagination of the entire country. The New York Times, in its travel section, announced the visionary scheme: "One of the unusual features of this historic city is the San Antonio
River, which meanders lazily through the downtown business district between tree-shaded banks. Recognizing its scenic value, the city has never permitted it to be covered or diverted." They then described the work to be done to make it "the city where you shop from gondolas" (New York Times, February 12, 1939). Finally, in mid-March, the City was able to announce that ground-breaking ceremonies would be held on March 24, on the river bank opposite the Smith-Young Tower (SAE, March 19, 1939). "Holding a golden shovel, Jack White, whose enthusiasm and persistency brought the dream to earth, turned the first shovel of earth for the project on the river frontage." The first phase involved a four-block section between the Plaza Hotel and the East Market Street bridge. Presiding as master of ceremonies, Walter S. Napier, president of the Chamber of Commerce, paid tribute to White and the property owners whose vision had "carried the project through to actuality." J. A. Hazelrigg, WPA administrator for the district, pledged the cooperation of the government in carrying out its share of the project. Mayor Quin recalled the history of the development of the idea and gave credit to those who had brought it about. "For a few silent moments the crowd was ask to bow their heads in memorial tribute to Ed Arneson." (SAE, March 25, 1939). Tom McNamara was employed as construction supervisor and Robert H. Turk assigned as project superintendent.

By May, most of the preliminary clearing and dredging had been completed and the actual construction began. City council accepted bids for the materials required: from John M. Harris Company, 5,500 pounds of dynamite and caps; hydrated lime from the Bird Lime and Cement Company, and sand and washed gravel from the Leon Sand and Gravel Company (SAE, May $12,1939)$. The flow of the river had been diverted into the cut-off channel to allow construction to be accomplished without the use of pumps.

By June, work had progressed to the point that some citizens became alarmed, charging "that fine old trees and plants along the river were being ruthlessly destroyed in the WPA river beautification." Hugman was quick to counter their concerns by reporting the methods he was employing to preserve the natural setting of the river. "In construction of natural rock walls for floral and shrub terraces, the WPA workers 
have carefully removed the soil from about the roots of trees so as not to damage the roots. When the rocks are placed into position, the roots are covered with paper also to prevent any injury." He stated that since the river had been dammed they were required to water the plants on a regular basis. In many cases, the native plants were endangered by construction, requiring their removal to a safe area where they were cared for by the workers. "Walls are being constructed to follow the natural winding current of the river and in some instances to emphasize the curves. Walks are being built with a shelving edge above the portion which will be below water level. The edges of these overhanging rock walks will be covered with climbing plants with only outcroppings of rock showing to give a natural effect" (SAE, June 14, 1939).

In October, City officials were notified by Sen. Tom Connally, that an additional $\$ 483,395$ had been approved for the second phase of the river beautification. This allowed the project to extend up beyond the "Big Bend" to the Municipal Auditorium. The funding, also, allowed for the inclusion of the adjacent parks, surface drainage facilities, walks, stairs, and retaining walls. "With costs of operating the first unit in the downtown area running approximately 20 per cent below estimates, it will be possible to extend the beautification program beyond the Municipal Auditorium point, WPA officials believe" (SAE, October 15, 1939). In September, the commissioners contracted with Alamo Iron Works to supply the flood gate for installation at the head of the "Big Bend" section.

The contract called for a payment of $\$ 1313.00$ for the gates, to include "guides, hoist, cables and cable links and hooks for supporting the gates" (City Commissioner's Proceedings, Vol. Q, p. 80, September 1, 1939). By December, it was possible to open the floods gates and return water to the bend for the first time since March. Jack White opened the gates to return water to the newly completed first phase just prior to Christmas; work on the second portion was scheduled to begin shortly after January 1 (SAE, December 24, 1939). Also, the City decided to purchase a barge mounted "with an engine that will be the motive power as well as the power for a sprinkling system for watering the plants on the river bank" (SAE, December 29, 1939).
As the first phase of the river beautification drew to a conclusion, the visionary who made it possible was summarily discharged from the project. On March 19, 1940, the commissioners met in council and enacted Ordinance 1568: "It is declared that the contract entered into, by, and between the City of San Antonio and R. H. H. Hugman, entered into, and approved by ordinance dated December 15, 1938, is terminated" (City Commissioner's Proceeding, Vol. Q, p. 520, March 19, 1940; Ordinance Book J:89). The discussion among the commissioners prior to the dismissal was not recorded, but the official reason given was that Hugman had breached his contract by failing to employ a landscape architect and supply plans that had been previously requested (Zunker 1983:12).

In his press statement, following the action, Hugman charged that it was a result of his failure to hire a landscape architect "who is close to Mayor Maverick politically" at $\$ 35$ a week from his own pocket. "My discharge from the river improvement project was a specimen of machine politics with the present city projects." His dismissal was approved by his old friend Jack White, as head of the beautification committee, who added that some cost estimates were erroneous. Hugman's response indicated that there was more to his firing than was being released: "I seriously doubt that any member of the river improvement committee except the chairman approved my discharge. There were reasons for that hostility on the part of the chairman also" (SAE, March 22, 1940). Thirty years later, Hugman would state that the actual reason for his ouster was because "materials originally ordered for the river project went instead to the La Villita project which was also under construction." He presented proof of this to Judge Claude V. Birkhead, a member of the river beautification board, who insisted that a closed meeting be called. The result was that Hugman was fired without a hearing (Zunker 1983:13). His replacement was architect J. Fred Beunz, member of the San Antonio park advisory and planning board.

By May of 1940, work had progressed to the point that the huge gates fabricated by Alamo Iron Works were ready for installation. Set behind graceful arches, just to the west of the St. Mary's Street bridge, their purpose was to control the water flowing into the "Big Bend" south to the spillway located near the Plaza Hotel. During times of high water the gates were to 
be closed, forcing the water into the cut-off channel around the downtown portion (SAE, May 7, 1940). The City also launched the "city navy," Miss San Antonio, a small boat fitted with a water nozzle to be used to irrigate plantings along the banks. The vessel was tested in Brackenridge by Jack White, Tom McNamara, and O. W. Wilson, the builder, and declared to be "river worthy." O. R. Murray was employed to spray the plants daily by means of a water spray from the pump aboard producing 70-pounds of pressure (SAE, May 18, August 5, 1940).

Mrs. Ethel Wilson Harris, later custodian of San José Mission, was supervisor of another WPA project, the production of colored tiles to be used to mark historic landmarks and decorate restored structures. She and her workers created two tile mosaics for the river walk. The first was installed near the flood gates by an old twin-trunk cypress and read:

"An old legend describes this twin cypress as a lookout of a Mexican sniper who picked off the Texans as they came to the river for water."

The second plaque was installed at the Navarro Street bridge:

"Old Mill Crossing plaque, last known place where horses drank and forded the river.

Dedicated to the memory of our fatherserected by the Daughters of Texas Trail Drivers" (Hugman 1968:10; SAE, August 4, 1940).

This plaque was officially dedicated at a program for the convention of the Daughters of Texas Trail Drivers some two years later (SAE, April 17, 1942).

On Wednesday, August 7, the first phase of the beautification, which had employed a crew of 389 workers, at the peak of construction, was declared complete. Construction continued on the second phase, from the "Big Bend" section to the Fourth Street bridge (near the Municipal Auditorium), which was expected to cost an additional $\$ 190,000$. Phase One covered about a mile and a quarter of the river through the business section of the City.

\author{
"Stairways built of native stone, many \\ with decorated iron grillwork railings made by \\ native Mexican craftsmen in the WPA \\ craft project, give access to the paths \\ along the river. \\ Walks of colored tile interspersed \\ with footpaths for variety footbridges, \\ benches of native stone and wood, \\ the latter made in the craft shop \\ of the WPA, flower beds and shrubbery, \\ fountains and a river theater are the facilities \\ and scenic beauty offerings of the completed area"
} (SAE, August 8, 1940).

By March of 1941, the remaining work on the project was completed -the gates were opened and water was turned back into the entire downtown channel.

Since its beginning in the spring of 1939, the project, which stretched from South St. Mary's bridge to the Fourth Street bridge, had improved twenty-one blocks, some 8,500 feet of riverbank. "Construction included 17,000 feet of river walls and sidewalks, 11,000 cubic yards of masonry and 3,200 yards of concrete. Thirtyone stairways constructed from street level to the river were built, each stairway of a different design" (SAE, March 14, 1941). The stairways were cantilevered and, therefore, not required to be attached to street level structures.

The largest unit constructed was the Arneson Theater with dressing rooms and stage on one bank of the river and seating for 1,000 on the opposite bank. Landscaping required planting of over 4,000 trees, including 1,800 banana trees. The cost of the project was $\$ 442,900$, of which $\$ 82,700$ was supplied by sponsors to defray the City's obligation. The next month the City published an attractive brochure as a final report to the public. In the foreword, was a special dedication:

\footnotetext{
"It remains for two practical men with vision to conceive the fulfillment of these hopes...

The late Edwin P. Arneson, engineer, in whose memory the Arneson River Theater has been named,

and R. H. H. Hugman, architect, converted the hopes into plans which have now been developed into beautiful reality."
} 
With the release of the final report, the mayor made several statements that reflected the problems that would soon arise with the utilization of this wonderful asset. He assured the merchants that "the improvement of adjoining properties would be gradual and there was no intention now of harassing anyone in an intensive campaign to have work done now," and that "lighting of the improved section of the river would be undertaken but time would be required as the expense would be so heavy that some plans must be made in the city's financial setup" (SAE, April 13, 1941).

The Japanese attack on Pearl Harbor on December 7, 1941 brought the United States into another global war. Only six months after its completion, the festive frivolity of carnival atmosphere for which the river walk had been created seemed inappropriate in the face of the conflict that the nation now devoted its full effort to ending. "War dethroned the King and Queen of the 1942 Fiesta de San Jacinto in San Antonio, but elevated their "subjects" to the job of liquidating the dictators. San Antonio sacrificed this year's Fiesta and its climactic Battle of Flowers for the war effort." The press echoed the reality that had reached almost every family, that the men who had planned the spectacular 1941 activities “today have answered Uncle Sam's call" (SAE, April 24, 1942). Only the solemn "pilgrimage to the Alamo" to honor the fallen who gave their lives for liberty seemed appropriate, and this was the only event conducted during the next five years. San Antonio turned its efforts toward what it had always done best: serving and training the military forces.

The ensuing years created a condition of benign neglect on the river that negated much of the charm that the beautification had produced. As the mayor's dedication address indicated, there was no concerted effort to force the property owners to develop the potential offered by investing in open river frontage shops or restaurants. The City was not disposed to devote funds to lighting or patrolling an area that had little use as a result of the wartime austerity. As a result, the river became an undesirable area, subject to frequent muggings, robberies, and intimidations. By the 1950 s, only two establishments catered to the few visitors to the river and many areas had been declared "off-limits" by the military authorities. Business owners in the heart of the City became concerned with the growing exodus of shoppers and diners to suburban shopping malls, and began to seek ways of bringing business and tourism back to the downtown area.

In the late-1950s, businessmen Arthur "Hap" Veltman and David Straus approached Harold Robbins of the Chamber of Commerce and Robert Frazier, Director of Parks and Recreation, with the concept of revitalizing the river walk. A fund of $\$ 15,000$ was raised and matched by the City to obtain a feasibility study to determine the direction that should be taken with the river bend. This resulted in the creation of the River Walk District and Advisory Commission in 1962 and a master plan was developed and presented to the voters, who passed a \$500,000 bond issue in January 1964.

At that time, the Paseo del Rio Association, an advisory group of businessmen and property owners along the river walk, was established (Zunker 1983:14). Under their direction the river bend area was returned to its former splendor, and an extensive, nationwide publicity campaign begun. Finally, linkage to San Antonio's HemisFair of 1968 helped to further develop the City's major tourist destination.

\section{Results of Site Assessment Visits}

As part of the San Antonio River Improvements Project, staff archaeologists from the Center for Archaeological Research at The University of Texas at San Antonio, conducted two separate site assessment visits while the northern section of the San Antonio River was drained in May of 1999 and January, 2000.

During the initial inspection, four areas of potential concern were located within the pilot channel:

1) Site of the historic Laux Mill;

2) An accumulation of small limestone rocks thought to represent part of a pre-1873 footbridge between Augusta and Convent streets;

3) A small dam constructed in the $1920 \mathrm{~s}$ as part of the original river improvement project;

4) A deposit of mid- to late-nineteenth-century artifacts in the profile of the river channel. 
These locations were revisited in January, 2000, and a reevaluation was made. Area 2, where limestone rocks may have represented a possible footbridge remnant, on closer inspection was determined to be a collapsed portion of the river-channel retaining wall. It was removed from the list of areas of possible concern. Also Area 3, where the 1920s stone dam was located, was eliminated as it is positioned outside the northernmost boundary of the current project area.
The two remaining locations indicated, Area 1 -Laux Mill and Area 4-the 1800s artifact deposit, were found to be valid areas of potential concern. The location and present extent of both of these sites was documented (Figure 6) and site forms were filed with the Texas Historical Commission. A full description of the currently visible remains of each follows.

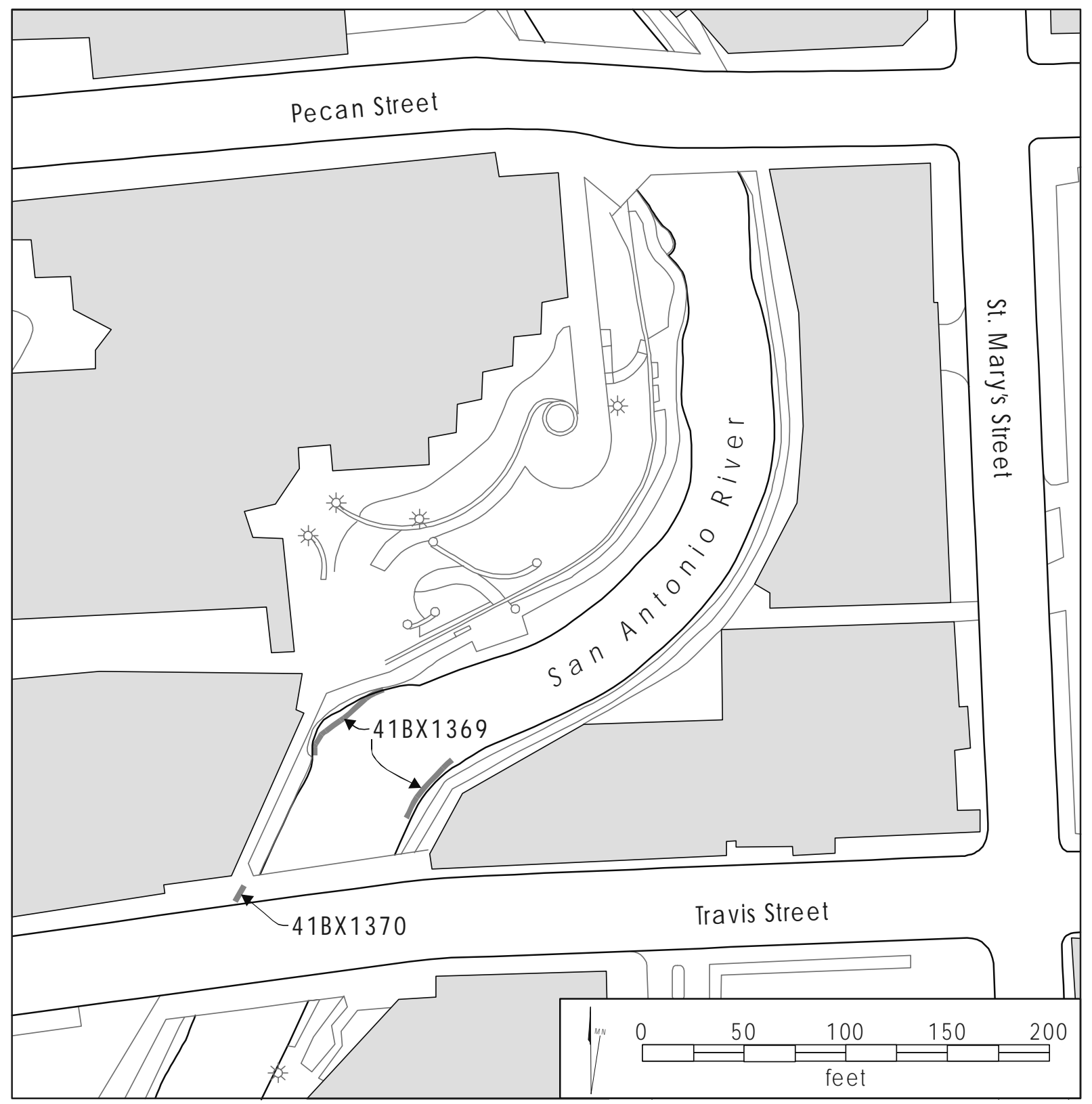

Figure 6. Location of recorded sites within project area. 41BX1369 is Hugman's water feature and location of Laux Mill and Dam, 41BX1370 is an 1840s artifact deposit beneath Travis Street Bridge and Riverwalk sidewalk. 


\section{Laux Mill and Dam}

Approximately 600 feet north of the Houston Street bridge and immediately north of the Travis Street bridge, on the west bank of the river is a water feature designed and built by Hugman (Figure 7). We believe that this water feature is located at the site of the historic Laux Mill and portions of it may have been incorporated into Hugman's feature. This mill was built ca. 1866 and continued to operate until 1882. It had a platform extending into the river that probably contained the mill wheel (Figure 8). There was also a small stone dam associated with the mill that crossed the river at the southern end of the property. The platform and dam are still visible on the 1896 Sanborn map when the mill structure was in use as a boarding house (see Figure 4).

At the time of the site visit, no physical evidence of the actual mill or millrace were visible. It is speculated that if portions do remain, they would be under the existing concrete water feature and sidewalk. Several large limestone blocks, possibly from the mill or its divergence dam, still remain in the bottom of the channel. The historic location of the Laux Mill and Dam is recorded with the Texas Historical Commission and assigned State Trinomial 41BX1369 (Figure 6).

\section{0s Artifact Deposit}

As the river reached its maximum low point during draining, a deposit was revealed in the profile of the pilot channel wall on the west bank of the river at the Travis Street bridge (Figure 6). The top of the deposit begins directly below the stone retaining wall, at a depth of 63 inches below the surface of the river walk sidewalk, and continues to 74 inches below the sidewalk where the river bottom begins (Figure 9). The vertical and horizontal extent of this deposit could not be determined during this site visit.

A slight degree of difference was noted in the soils forming this deposit. The upper $1-5$ inches is dark gray almost black in color while the lower 10 inches is a lighter gray. The upper deposit contains late-nineteenthcentury artifacts including a prescription bottle from B. W. Bristow Druggist, in business in San Antonio between 1895-1897 and a piece of undecorated ironstone with a maker's mark used by A. J. Wilkinson ca. 1896. Although, no diagnostic artifacts were recovered from the lower deposit, the combination of lead-glazed, edge decorated, and banded slip ceramics strongly suggests a date of ca. 1840 .

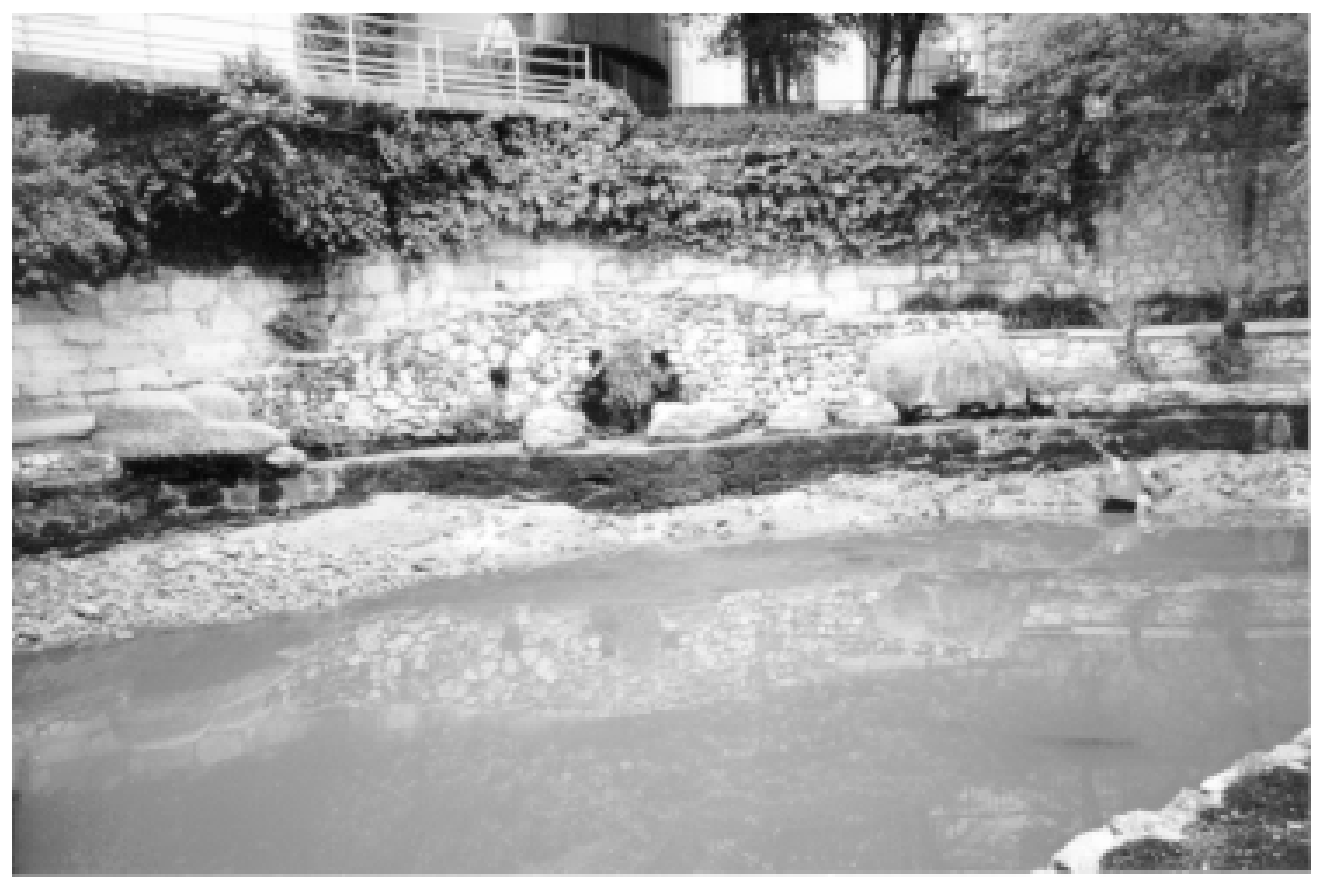

Figure 7. 41BX1369 - Hugman water feature, probable location of Laux Mill. 


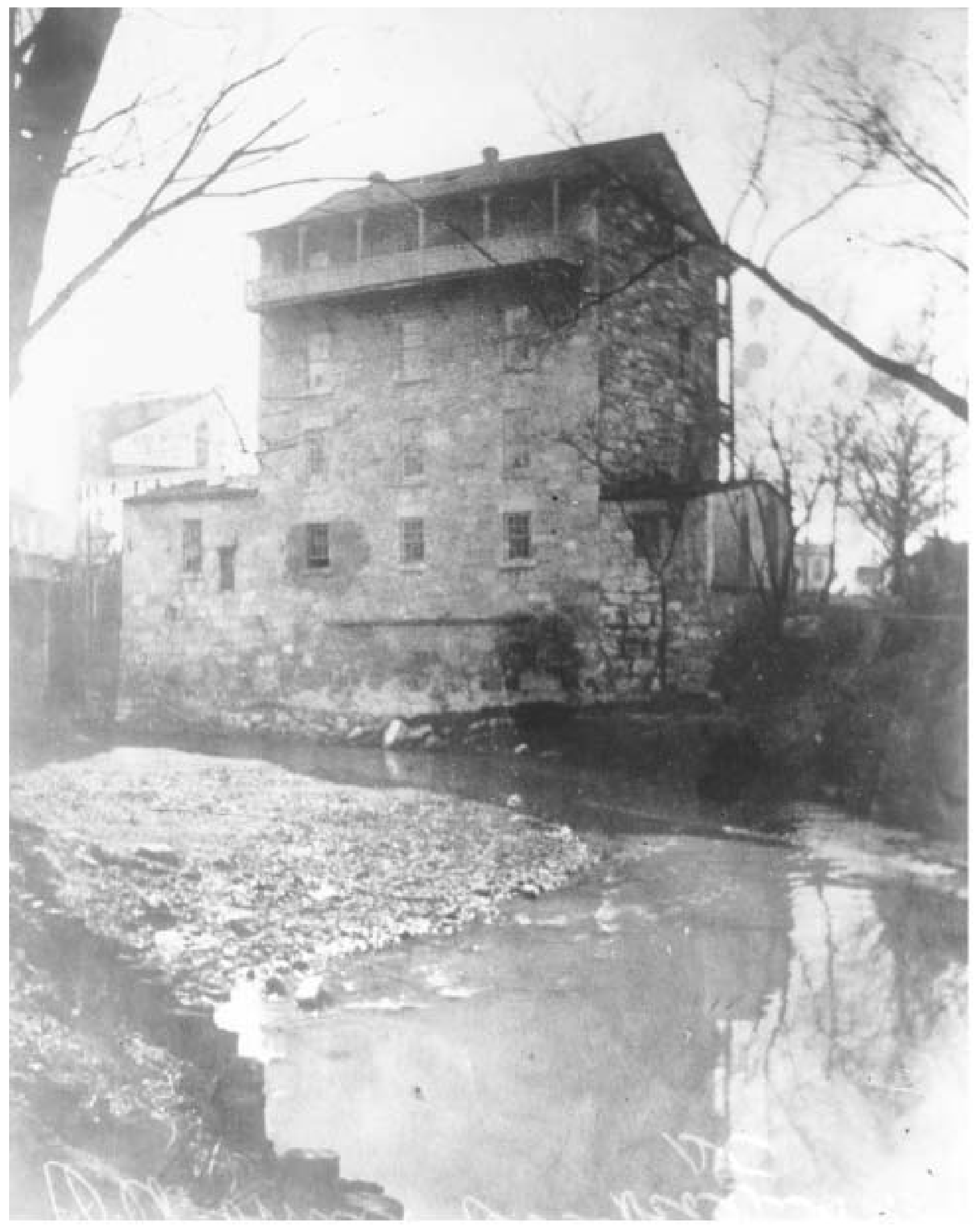

Figure 8. Photo of Laux Mill (n.d.) published June 10, 1930, from the San Antonio Light collection. Photograph courtesy of The UT Institute of Texan Cultures at San Antonio. No. 1229-Q. 
Figure 9. 41BX1370 - Artifact deposit beneath pilot channel retaining wall.

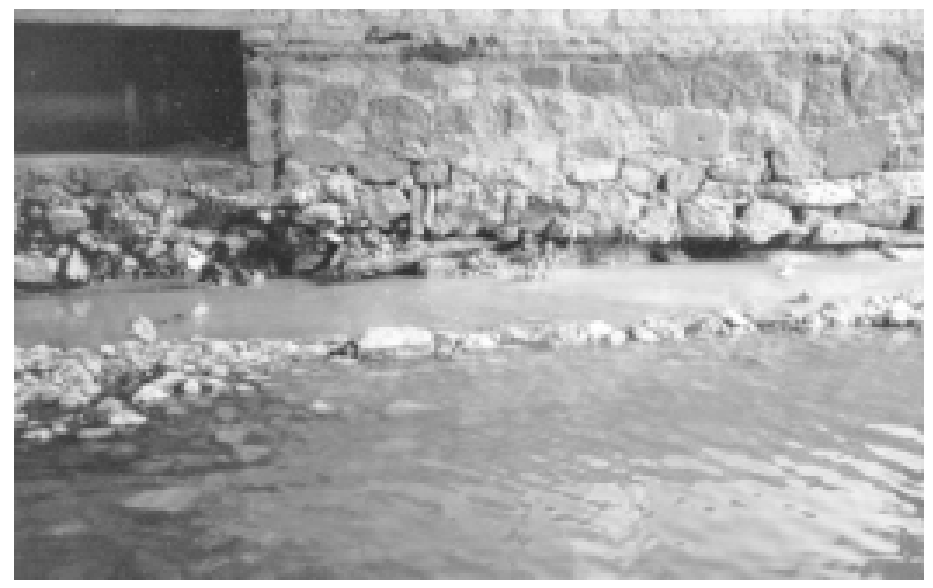

This area of the river would have been directly behind the home of William Jaques, shown on the 1896 Sanborn map as 304 Soledad Street (see Figure 4). This home was constructed in 1842 and stood until 1900. It is probable that the artifact deposit visible in the wall of the west bank of the river is related to the occupation of this home. The historic artifact deposit in the west bank of the river beneath the Travis Street bridge has been documented and recorded with the Texas Historical Commission. It has been assigned State Trinomial 41BX1370.

\section{Conclusions and Recommendations}

The results of the archival study and site inspections indicate that within the study area there appear to be relatively few locations which warrant consideration for further archaeological investigation. The area described previously (41BX1369), formerly occupied by the Laux Mill is one of these. The existence of a landscape feature designed by Robert Hugman appears to occupy the location of the old millrace. According to the guidelines established for this project by the archaeological division of THC, the ca. 1866 mill with its associated dam does not fall within the pre-1850 time frame for archaeological significance but may qualify as "unique or rare deposits post-dating 1850." Considering this structure was one of San Antonio's earliest mills and had historical significance during its sixty-year existence, special consideration should be taken when designing improvements in this area. We recommend that impact to this area be avoided. If this is not possible, qualified personnel should be on hand to monitor any destructive modifications outside of the river channel to determine if portions of the mill or millrace have survived. If remnants are identified, THC and COE will need to be consulted for recommendations on further work.

Currently, the extent and integrity of the lower level of the cultural deposit (41BX1370) beneath the Travis Street bridge remains unknown. In all likelihood, any portion of the deposit that extended into the river channel has been destroyed. The possibility exists, however, that intact deposits may continue behind the pilot channel wall and beneath the existing sidewalk. As this deposit appears related to the 1842 Jaques homestead, it does fall within the pre-1850 time frame for archaeological significance established by THC. Again, avoidance is recommended. However, if this is not possible, qualified personnel will need to be on hand during modifications to identify the remaining extent of this deposit. If intact portions remain, THC and COE will need to be consulted for recommendations on further work before modifications can continue.

The above recommendations are based on archival research and two very preliminary site inspections. The possibility remains that historic or prehistoric deposits may also be present behind the pilot channel walls, beneath the sidewalks, or behind the above channel walls. However, we feel that, due to the nature of the river and its various flooding episodes, any archaeological deposits that exist in the river bottom itself would no longer be in their original context and would not be archaeologically significant. Therefore, on-site monitoring during construction activities involving subsurface disturbances, excluding river-bottom dredging, is highly recommended.

Additionally, this report has identified several areas that would lend themselves to interpretive signage to identify historically significant sites, such as the Jaques and Paschal homes, the Laux Mill, the Ursuline Academy, and the two early acequias. While these sites have either been destroyed or will not be directly affected by this project, they still retain historic significance and this information should be presented to the public by means of signage or wayside plaques. 


\section{References Cited}

Castañeda, C. E.

1936 Our Catholic Heritage in Texas. In Five Volumes, Von Boeckman-Jones, Austin.

Chabot, F. C.

1937 With the Makers of San Antonio. Privately published, Artes Graficas, San Antonio.

de la Teja, J. F.

1995 San Antonio de Béxar, A Community on New Spain's Northern Frontier. University of New Mexico Press, Albuquerque.

Edwards, E.

1981 Stones, Bells, Lighted Candles: Personal Memories of the Old Ursuline Academy In San Antonio at the Turn of the Century. Daughters of the Republic of Texas Library, San Antonio.

Ellsworth, C. E.

1923 The Floods in Central Texas In September, 1921. Department of the Interior, United States Geological Survey, Water Supply Paper 488, Government Printing Office, Washington.

Fisher, L. F.

1996 Saving San Antonio: The Precarious Preservation of a Heritage. Texas Tech University, Lubbock

Hoffman, F. L. (translator)

1935 Diary of the Alarcón Expedition into Texas: 1718-1719, by Fray Francisco Céliz. The Quivira Society, Los Angeles

Hugman, R. H. H.

1968 "How Paseo Del Rio, by the Architect". Unpublished manuscript, Files of the San Antonio Conservation Society, Wulff House, San Antonio

James, V. L.

1938 Frontier and Pioneer Recollections of Early Days in San Antonio and West Texas. Artes Graficas, San Antonio.

Jones, C. J.

1983 Archaeological Investigations of the Southeast Building Complex, Old Ursuline Academy Campus, 41 BX 235, San Antonio, Texas. Archaeological Survey Report No 118. Center for Archaeological Research, The University of Texas at San Antonio.

Metcalf and Eddy

1920 Report to City Of San Antonio, Texas Upon Flood Prevention. Metcalf \& Eddy, Consulting Engineers, 14 Beacon St., Boston, Mass. December 6.

New York Times

1939 "Gondolas For Texans", Travel Section, February 12. 
Pease, S. W.

n.d. They Came to San Antonio. Mimeographed copy in the Library of the Daughters of the Republic of Texas, San Antonio.

San Antonio Express

1888 "Funeral Notice," June 28.

1913 "River on Rampage," October 2.

"Damage From Flood May Reach Quarter Million," October 3.

"To Prevent Future Floods the Mayor Considers Olmos Plan," October 4.

"Loss Small, Measured by Last Flood," December 5.

1919 "People To Choose Site -Mayor Bell," May 25.

"Build New Auditorium on Central Site Citizens Urge." July 29.

"Let the People choose the Auditorium site -for Their Convenience," July 31.

"City Buys Land Near Mentioned Auditorium Site," December 2.

“\$16,000 More Bond Money Put In Lot," December 12.

1920 "Widen Downtown Streets; Traffic Will Flow Freely," December 19.

1921 "Timely Showers Revive Ranges in Southwest Texas," September 9.

"Refugees Flee Safety from Path of Floodwaters," September 11.

1923 “\$4,350,000 City Bond Election Is Called For Tuesday, Dec. 4”, October 26.

"Tuesday's Vote On Bonds Turning Point, Says Tobin", December 4.

"Flood Prevention Bond Issue Carries", December 5.

1924 "C. F. Crecelius Recommended By City Advisory Committee As Flood Engineer", August 26.

"Two Years Required To Build \$1,500,000 Dam Across Olmos", August 31.

1925 "Street Once River Channel." February 1.

1926 "City Buys River Channel Land", March 16.

"\$175,000 Voted For New Channel", June 15.

"Finishing Touches Put to Huge Dam", August 28.

1927 "River Walls Extended," April 6.

1929 "Bids Called For in River Program", February 19.

"\$153,265 Lowest of Eight Bids For Big Bend Auxiliary Channel Across Commerce St.", March 12.

"Home Firm Given Channel Work", March 20.

"Plans To Beautify 'Big Bend Meets Mayor's Approval”, June 27.

"Preliminary Steps Toward Creation Of Miniature 'Old World Street' Along Big Bend Taken At

Meeting", June 29.

"City Considers Wrecking Bridge", July 13.

"Prize City Plan Condemned", July 16.

"City Plan Expert To Be Employed", July 19.

"River Cut-off Bids To Be Asked", September 6.

1930 "Great Bend Work Accepted", March 18.

"New Construction In City", April 27.

1935 "Sympathy City's Offer In Clean-up", August 14.

"Architect Tells Of River Beauty", October 1.

1936 "River Improvement And Beautification Begins", January 8.

1937 “White Started In 'Front Office' In Successful Climb”, August 1. 
1938 "Extensive Beautification Of Property Along The San Antonio River Proposed", April 24.

"River Beautification Meets City Snag", April 29.

"Hotel Men Back River Project", June 7.

"Bonds Approved For River Work", October 26.

"Plans Speeded For River Work", October 27.

"River Bond Bids Submitted Today", November 3.

"City Considering Two Bond Bids", November 4.

"Bond Bid Revised To Get WPA Aid", November 11.

"River Bonds Set For Certification", December 1.

1939 "River Beautification Project To Start At Ceremony Friday", March 19.

“Ceremony Starts \$4,265,000 River Beautification”, March 25.

"City Buys For River Project", May 12.

"Trees Being Preserved In Area Of River Beautification Work", June 14.

"Water Fills River Bend", December 24.

"City To Buy River Barge", December 29.

1940 "Beunz To Boss River Project", March 22.

"Flood Gates Ready", May 7.

"City Navy Launches Unit", May 18.

"Tree Undergoes Operation", August 4.

"Floating Water Wagon", August 5.

"Finishing Touches Given First Phase Of River Beautification", August 8.

1941 "River Beautification Project Turned Over To City By WPA", March 14.

"City Lauds Architect It Discharged", April 13.

1942 "In Plaque Dedication", April 17.

"A New Parade Loop Is Being Formed", April 24.

1957 “Mile-high Milam,” January 28.

San Antonio Express-News

1989 "476 properties foreclosed on July $4^{\text {th }}$," July 5.

1995 "The bridges of San Antonio something to see," June 26.

San Antonio Light

1911 "Travis Street Bridge Too Narrow," January 27.

"Pecan Street Extension," February 22.

1913 "Woman, pioneer of State, Dies at 84," May 14.

Santos, R. G.

1981 Aguayo Expedition Into Texas, An Annotated Translation of the Five Versions of the Diary Kept by Br. Juan Antonio de la Peña. Jenkins Publishing Company, Austin, Texas.

Schuetz, M. K.

1968 History and Archeology of Mission San Juan Capistrano, San Antonio, Texas. Report Number 10, Volume 1. State Building Commission Archeology Program, , Austin.

Steinfeldt, C,

1978 San Antonio Was: Seen Through a Magic Lantern. San Antonio Museum Association, San Antonio. 
Turanza, J. P. (editor)

1961 Documentos para la Historia Eclesiastica y Civil del la Provinca de Texas o Nueva Philipinas, 1720-1779. Coleccion Chimalistac de Libros y Documentos Aceria la Nueva España, Marid, Spain.

Tyler, R. (editor)

1996 The New Handbook of Texas. In Six Volumes, The Texas State Historical Association, Austin.

Zunker, V. G.

1983 A Dream Come True: Robert Hugman and San Antonio's River Walk. Privately Published, San Antonio, Texas 


\section{Appendix I. \\ Text of Dedication Plaques on San Antonio River Bridges}

\section{North St. Mary's Street Bridge \\ 1915}

Clinton G. Brown, Mayor

Aldermen: J. R. Balwin, F. A. Chapa, L. M. Dielmann, W. L. Hoefgen, R. Lambert, J. A. K. Nicolaysen. Bridge Engineer: Hans Helland, City Engineer. Contractor: J. H. Richardson Co. Houston, Texas

\section{Romana Street Bridge (Navarro)} 1921

Sam C. Bell, Mayor

Commissioners-Louis Heuermann, Ray Lambert, Phil Wright, Andres Coy

Bartlett \& Ranney, Inc Engineers

Hans Hellard, City Engineer

Contractor: McKenzie Construction Company

Lexington Avenue Bridge (Fourth Street) 1926

John W. Tobin, Mayor

Commissioners-Ray Lambert, Paul E. Steffler, Frank H. Bushick, Phil Wright

I. Ewig, City Engineer

Contractor: Pryor and Jefferson

C. Raeber, Bridge Engineer

\section{Martin Street and Pecan Street Bridges}

1927

John W. Tobin, Mayor

Commissioners-Ray Lambert, Paul E. Steffler, Frank H. Bushick, Phil Wright

Contractor: J. G. Jefferey

C. Raeber, Bridge Engineer

\section{Travis Street Bridge}

1929

C. H. Chambers, Mayor

Commissioners - Jacob Rubiola, Paul E. Steffler, Frank H. Bushick, Phil Wright

I. Ewig, City Engineer

Contractor: J. G. Jefferey

C. Raeber, Bridge Engineer

\section{Convent Street Bridge}

1929

C. H. Chambers, Mayor

Commissioners-Jacob Rubiola, Paul E. Steffler, Frank H. Bushick, Phil Wright

I. Ewig, City Engineer

Contractor: J. G. Jefferey

C. Raeber, Bridge Engineer

\section{Richmond Street Bridge}

1930

C. H. Chambers, Mayor

Commissioners-Jacob Rubiola, Paul E. Steffler,

Frank H. Bushick, Phil Wright

I. Ewig, City Engineer

Contractor: J. G. Jefferey

C. Raeber, Bridge Engineer 